\title{
Monophyly of Heterandriini (Teleostei: Poeciliidae) revisited: a critical review of the data
}

\author{
Alfy Morales-Cazan and James S. Albert
}

\begin{abstract}
The systematics and taxonomy of poeciliid fishes (guppies and allies) remain poorly understood despite the relative importance of these species as model systems in the biological sciences. This study focuses on testing the monophyly of the nominal poeciliine tribe Heterandriini and the genus Heterandria, through examination of the morphological characters on which the current classification is based. These characters include aspects of body shape (morphometrics), scale and fin-ray counts (meristics), pigmentation, the cephalic laterosensory system, and osteological features of the neurocranium, oral jaws and suspensorium, branchial basket, pectoral girdle, and the gonopodium and its supports. A Maximum Parsimony analysis was conducted of 150 characters coded for 56 poeciliid and outgroup species, including 22 of 45 heterandriin species (from the accounted in Parenti \& Rauchenberger, 1989), or seven of nine heterandriin species (from the accounted in Lucinda \& Reis, 2005). Multistate characters were analyzed as both unordered and ordered, and iterative a posteriori weighting was used to improve tree resolution. Tree topologies obtained from these analyses support the monophyly of the Middle American species of "Heterandria," which based on available phylogenetic information, are herein reassigned to the genus Pseudoxiphophorus. None of the characters used in previous studies to characterize the nominal taxon Heterandriini are found to be unambiguously diagnostic. Some of these characters are shared with species in other poeciliid tribes, and others are reversed within the Heterandriini. These results support the hypothesis that Pseudoxiphophorus is monophyletic, and that this clade is not the closest relative of H. formosa (the type species) from southeastern North America. Available morphological data are not sufficient to assess the phylogenetic relationships of $H$. formos $a$ with respect to other members of the Heterandriini. The results further suggest that most tribe-level taxa of the Poeciliinae are not monophyletic, and that further work remains to resolve the evolutionary relationships of this group.
\end{abstract}

La sistemática y taxonomía de poeciliídos (gupys, platys, mollys y espadas) continúa siendo poco conocida, a pesar de su importancia como modelos experimentales en ciencias biológicas. Este estudio busca probar la monofilia de la tribu nominal Heterandriini (Poeciliinae) y del género Heterandria, mediante el estudio de los caracteres morfológicos en los que se basa la clasificación actual. Estos caracteres incluyen aspectos como la forma del cuerpo (morfometría), conteos de escalas y radios de las aletas (merísticos), pigmentación, sistema sensorial cefálico y características osteológicas del neurocráneo, mandíbula y su suspensorio, canasta branquial, cintura escapular y del gonopodio y sus soportes. Se condujo un análisis de Maxima Parsimonia con 150 caracteres codificados para 56 poeciliídos y especies del grupo externo, incluyendo 22 de 45 especies de Heterandriini (según el conteo de Parenti \& Rauchenberger, 1989), o siete de nueve especies (según el conteo de Lucinda \& Reis, 2005). Los caracteres con estados multiples fueron analizando de manera ordenada y no ordenada seguido de una ponderación iterativa $a$ posteriori para mejorar la resolución de los árboles. Las topologías de los árboles obtenidos de estos análisis apoyan la monofilia de las species mesoamerianas de "Heterandria”, que de acuerdo a la información filogenética disponible, son aquí reasignados al género Pseudoxiphophorus. Ninguno de los caracteres usados en estudios previos para caracterizar el taxón nominal Heterandriini fue encontrado de forma inequívoca diagnóstico. Algunos de estos caracteres son compartidos con especies de otras tribus de poeciliídos y otros han revertido entre Heterandriini. Estos resultados apoyan la hipótesis de que Pseudoxiphophorus es monofilético, y que este grupo no es grupo cercano de $H$. formosa (la especie tipo) del sudeste de Norte América. La información morfológica disponible no es suficiente para evaluar las relaciones de $H$. formosa con respecto a otros grupos de Heterandriini. Los resultados de este estudio sugieren que la mayoría de taxones a nivel de tribu de Poeciliinae no son monofiléticos, y que aún queda trabajo para resolver las relaciones evolucionarias de este grupo.

Key words: Fish diversity, Heterandria, Ichthyology, Osteology, Pseudoxiphophorus, Systematics.

University of Louisiana at Lafayette, Department of Biology , Lafayette, LA, 70504-2451, USA. aam3349@1ouisiana.edu; jalbert@louisiana.edu. 


\section{Introduction}

The Poeciliidae (livebearers and relatives; sensu Ghedotti, 2000 ) is a clade of small-bodied (20-200 mm standard length) cyprinodontiform fishes with about 317 species currently recognized in 30 genera. Poeciliids are characterized by a suite of derived characters including the position of the pectoral fins high on side of the body, an anterior placement of the pelvic fins ventral to the pectoral fins, the presence of pleural ribs on the first several haemal arches, a bony cap on the ventral hypohyal lying over the anterior facet of the anterior ceratohyal, and supraorbital laterosensory pores with neuromasts embedded in fleshy grooves (Ghedotti, 2000). Despite the widespread use of poeciliid fishes in ecological and evolutionary studies (e.g., Rauchenberger, 1990; Meyer et al., 1994; Borrowsky et al., 1995; Marcus \& McCune, 1999; Spencer et al., 1999; Spencer et al., 2000; Morris et al., 2001; Kallman et al., 2004; Gutierrez-Rodriguez et al., 2007a, 2007b; Reznick et al., 2007; Leberg \& Firmin, 2008; Purcell et al., 2008; Martin et al., 2009; Pollux et al., 2009; Meredith et al., 2010; Pires et al., 2010; Albert \& Johnson, 2011), the phylogenetic interrelationships among poeciliid species remain incompletely resolved.

The family Poeciliidae comprises three subfamilies that are restricted to fresh and brackish continental waters: Poeciliinae, Procatopodinae, and Aplocheilichthyinae (Ghedotti, 2000; Lucinda, 2003; Hrbek et al., 2007). The Poeciliinae includes at least 228 species distributed across much of the tropical and subtropical portions of the Americas, from the La Plata estuary of northern Argentina to southeastern United States, with species richness reaching a zenith in Middle America and the West Indies (Rosen \& Bailey, 1963; Lucinda, 2003; Hrbek et al., 2007; Albert et al., 2011). The Procatopodinae includes at least 78 species in the humid tropical regions of South America (i.e. Fluviphylax) and Africa (Lucinda, 2003), and the Aplocheilichthyinae is represented by about 11 species of Aplocheilichthys from humid tropical regions of Africa (Huber, 1999).

All poeciliine species have internal fertilization achieved by means of an intromittent organ (gonopodium) in males, which is a modification of anal-fin rays 3-5. Poeciliine species bear their young as free-swimming juveniles (without a yolk sac), and exhibit either ovoviviparity (eggs hatch within the uterine cavity), or viviparity (maternal provisioning to the developing larvae while in the uterine cavity). The ovoviviparity condition is thought to be derived within the subfamily (Pollux et al., 2009). One poeciliine species, Tomeurus gracilis from northeastern South America, is facultatively ovoviviparous, releasing eggs or live young depending on environmental conditions (Breder \& Rosen, 1966; Wourms, 1981). The Poeciliinae is also characterized by several salient morphological features in addition to the gonopodium; expansion of the fourth epibranchial, absence of exoccipital condyles, and neural arches of the first vertebra open (Rosen \& Bailey, 1963; Parenti \& Rauchenberger, 1989; Ghedotti, 2000).

The name Heterandriini was introduced by Hubbs (1924) for a group of poeciliins in which the third ray of the gonopodium lacks a pair of curved horn-like projections, and in which the fifth ray always is smooth on the posterior edge. This group originally included nine genera; Allogambusia (now Priapichthys), Alloheterandria (now Priapichthys and Gambusia), Darienichthys (now Priapichthys), Heterandria, Neoheterandria, Panamichthys (now Priapichthys), Priapichthys, Pseudopoecilia, and Pseudoxiphophorus (treated as a subgenus by Rosen, 1979). Hubbs (1926) published diagnoses to identify each of these genera. According to Hubbs (1926), species of the tribe Heterandriini evolved in Central America and northwestern (trans-Andean) South America.

Rosen \& Bailey (1963) organized the Poeciliidae into five subfamilies, nine tribes, and 52 genera, primarily on the basis of similarities in the gonopodium and gonopodial suspensorium. They included six genera in the tribe Heterandriini; Heterandria, Neoheterandria, Phallichthys Poeciliopsis (which was divided into the subgenera Poeciliopsis and Aulophallus), and Priapichthys. The diagnostic characters of Heterandriini sensu Rosen \& Bailey (1963) were also largely taken from the gonopodial complex; i.e., gonopodial length more than one-third standard length, presence of three or more gonapophyses, moderately or welldeveloped ligastyle, and two to four plate-like gonactinosts. However, these traits are shared with species of other nominal poeciliine tribes, and are not in fact unique to species of the Heterandriini.

Several subsequent phylogenetic studies based on morphological (Rodriguez, 1997; Ghedotti, 2000; Lucinda \& Reis, 2005) and molecular (Hrbek et al., 2007) data suggest that some of the tribes proposed by Rosen \& Bailey (1963) are not monophyletic. These papers also show that some genera not previously placed in the Heterandriini (i.e., Alfaro, Brachyrhaphis, Pseudopoecilia, Neoheterandria) are more closely related to Heterandria formosa Girard (1859), the type species of the genus, than to the Middle American species of Heterandria which were previously assigned to Pseudoxiphophorus (Heckel, 1848). Despite these concerns, the pre-cladistic classification of Rosen \& Bailey (1963) remains the most recent comprehensive morphological revision and taxonomic authority for Poeciliidae (Lucinda, 2003; Hrbek et al., 2007). The Poeciliidae of Rosen and Bailey (1963) is equivalent to the Poeciliinae of Parenti (1981).

This study focuses on the systematics of the nominal poeciliine taxon Heterandriini (sensu Lucinda \& Reis, 2005) and the type genus Heterandria, using osteological and other morphological characters (morphometrics, meristics, pigmentation, and cephalic sensory system). As currently recognized, the Heterandriini includes five genera (Priapichthys, Neoheterandria, Heterandria, Poeciliopsis, and Phallichthys) with more than 60 species (Parenti \& Rauchenberger, 1989; Ghedotti, 2000). The goal of this study is to test the monophyly of the taxa Heterandriini and Heterandria by evaluating all the characters used historically in the higher classification of the group within a formal phylogenetic context. 


\section{Material and Methods}

A total of 56 species represented by 126 museum lots with more than 5,000 specimens were examined (Appendix 1). Museum abbreviations follow Leviton et al.,(1985), and can be found at Fricke \& Eschmeyer (2011) except USAC (Museo de Historia Natural de Escuela de Biologia, Universidad de San Carlos de Guatemala). The current definition of the Poeciliinae follows Parenti \& Rauchenberger (1989), which is equivalent to the Poeciliidae of Rosen \& Bailey (1963). Terminals were selected according to the list of species and previous taxonomic information for this group (see Rosen, 1979; Parenti, 1981; Greenfield, 1985; Rodriguez, 1997; Costa, 1998; Ghedotti, 1998, 2000; Lucinda \& Reis, 2005; Hrbek et $a l ., 2007)$ and available material in museums.

External characters, morphometrics, and meristics were examined from museum specimens of 66 species preserved in alcohol. Meristics and morphometrics followed the procedure outlined by Miller (1948) for cyprinodont fishes. Counts of scales in the lateral series follow Parenti (1981). All meristics and morphometrics were taken form the left side of specimens when possible using an Olympus SZX-12 dissecting microscope with 6-inch LCD digital caliper ( $\pm 0.1 \mathrm{~mm}$ error).

Clearing and staining for bones and cartilages followed the procedure of Taylor \& van Dyke (1985) with some modifications to account for the small size of the specimens. Oxygen peroxide and xylene were not used to avoid decalcification. Specimens were transferred directly from ethyl alcohol to Alcian Blue to maximize uptake of the hydrophobic stain. The viscera were removed after staining with Alcian blue because the small cartilages around the orbit are more apparent and the damage to the specimens is reduced (Reis, pers. comm., 2009). Prior to digestion in $30 \%$ trypsin solution (in sodium borate [NaBO]) specimens were treated one hour in $30 \% \mathrm{NaBO}$.

Dissections of cleared-and-stained fishes were made using microdissection tools following the method outlined by Weitzman (1974), and Ghedotti's (2000) modification of removing the branchial basket before the suspensorium. Bones were disarticulated to functional groups (e.g., neurocranium, suspensorium, pectoral girdle), or into individual elements (e.g., maxilla). Specimens from a total of 56 species were dissected and coded for phylogenetic analysis. Outlines and standardized features of individual bones or functional groups were traced from lateral and medial aspects with the aid of a camera lucida mounted on an Olympus SZX-12 dissecting microscope. Images were digitized using an HP Scanjet 5470c (2400dpi, 48-bit color) scanner and edited using Adobe Photoshop 7.0.

Descriptions of 150 characters and their alternative states are provided with characters organized by functional group (Appendix 2). Character states were polarized using conditions observed in outgroup taxa. Question marks were used to indicate when a character state could not be coded due to a lack of available specimens, or when the coding was non-sensical; e.g., state of the ligastyle (a free ossified haemal spine dorsal to the gonopodial suspensorium and close to the vertebral column) when a gonopodium is not present in the species. Whenever possible characters were coded for states observed in multiple specimens (Albert \& Crampton, 2005). Due to a lack of male specimens of Quintana and Fluviphylax gonopodial characters from these taxa were coded from literature. In most species, specimens of both sexes were examined, but in sexually dimorphic species only states observed in males were coded.

The names of teleost skeletal structures follow Patterson (1975). Anatomical nomenclature, other than that for the gonopodium, follows Rosen \& Bailey (1963), Parenti (1981), Rauchenberger (1989), and Lucinda \& Reis (2005). The number and disposition of cephalic pores follows Gosline (1949), Rosen \& Mendelson (1960), Parenti (1981), Rodriguez (1991), and Lucinda \& Reis (2005). Descriptions of gonopodial morphology were based on fully-developed gonopodia of large adult males. The nomenclature of the gonopodium, except were noted, follows Rosen \& Gordon (1951, 1953). Anal-fin ray terminology follows Rosen and Kallman (1959).

Microsoft Excel and Mesquite v. 2.72 (Maddison \& Maddison, 2009) software packages were used to assemble the data matrix of 56 taxa and 150 morphological characters. Characters were polarized using states in multiple outgroups, and character-state distributions were optimized in MacClade v. 4.0 PPC (Maddison \& Maddison, 1993). Poeciliid outgroups were selected from the results of previous studies, and included representative Anablepidae (Jenynsia eirmostigma, Anableps dowi), Profundulidae (Profundulus guatemalensis), and Aplocheilichthyinae (Fluviphylax pygmaeus); (Parenti \& Rauchenberger, 1989; Ghedotti, 2000; Lucinda \& Reis, 2005; Lucinda et al., 2006). Poeciliid taxa included 52 species in 21 genera, representing 22 of 45 species of Heterandriini sensu Parenti \& Rauchenberger (1989), which is equivalent to seven of nine species of Heterandriini sensu Lucinda \& Reis (2005).

A Maximum Parsimony (MP) analysis was conducted to find tree topologies that most economically summarized the data matrix; e.g., maximized similarities as synapomorphies and minimized them as homoplasies (Ane \& Sanderson, 2005; Campo et al., 2007; Albert, 2009). A heuristic search with the Tree-Bisection-Reconnection (TBR) algorithm was performed using PAUP* v. 4.0 b10 (Swofford, 1993, 2002). Multistate characters were analyzed as both unordered and ordered. Polytomies were resolved using a posteriori weighting on the rescaled consistency index (Farris, 1989; Albert, 2001; Kluge, 2001; Bryant, 2003; Kulkarni \& Moret, 2005). Bremer support (decay analysis) was used to assess node support (Bremer, 1988). Bremer support values were calculated using the reversedconstraint method (Sorenson, 1999) implemented in NONAv.2 (Goloboff, 1999a, 1999b; Goloboff et al., 2008) and Winclada v. 1.00.08 (Nixon, 2002) using the bremer.run script.

\section{Results}

These phylogenetic results are shown with multistate characters analyzed ordered and unordered, and used iterative weighting on the RC to resolve polytomies. The strict consensus tree of $12 \mathrm{MP}$ trees based on 150 unordered characters is given 
(Fig. 1; each tree 1430 steps, $\mathrm{CI}=0.20, \mathrm{RI}=0.48, \mathrm{RC}=0.10$ ). A single MP tree was obtained from analysis of this same dataset with all multistate characters treated as unordered and followed by a posteriori weighting based on the RC (Fig. 2; 1444 steps, CI $=0.20, \mathrm{RI}=0.47, \mathrm{RC}=0.09)$. A single MP tree with a slightly different topology (Fig. 3) was obtained when the multistate characters were treated as ordered (1446 steps, $\mathrm{CI}=0.20, \mathrm{RI}=$ $0.47, \mathrm{RC}=0.09)$. The strict consensus tree with all characters weighted equally, and with all multistate characters treated as unordered, is more-well resolved for the tribes Cnesterodontini, Scolichthyini, Gambusiini, and Alfarini (Fig. 1).

Bremer decay analysis showed that Poeciliopsis is well supported even though there was incongruence and lack of resolution within that clade. According to this study, several clades recognized in previous literature are well supported. These clades are: 1. Gambusia + Belonesox (Lucinda \& Reis, 2005; Hrbek et al., 2007); 2. Gambusia + Belonesox + Brachyrhaphis (Mojica et al., 1997); 3. Scolichthys + Neoheterandria (Lucinda \& Reis, 2005); 3. Limia + Xiphophorus (Rodriguez, 1997); 4. Limia + Xiphophorus (Rodriguez, 1997); 5. Pamphorichthys + Micropoecilia (Lucinda \& Reis, 2005) (see Fig. 1).

This study also suggests that the characters used in previous morphological analyses of Poeciliinae do not support the monophyly of Heterandriini. The monophyly of Heterandriini sensu Lucinda \& Reis (2005; see Table 3), including only species of the subgenera Heterandria and Pseudoxiphophorus was not supported by the results of this study. Heterandria formosa (the type species) was not found most closely related to Pseudoxiphophorus (from Mesoamerica) in any of the topologies recovered (Figs. 1-3). We therefore recommend restricting Heterandria to $H$. formosa (following Regan, 1913), and regard Pseudoxiphophorus as the valid name for the Mesoamerican clade (following Hubbs, 1924).

\section{Systematic account}

\section{Genus Pseudoxiphophorus Heckel, 1848}

Composition. Pseudoxiphophorus anzuetoi (Rosen, 1979); P. bimaculatus Heckel; P. cataractae (Rosen, 1979); P. diremptus (Rosen, 1979), P. jonesii Gunther, P. litoperas (Rosen, 1979), P. obliquus (Rosen, 1979).

Distribution. From the Tamesi river, Atlantic versant of Mexico ( $22^{\circ} 13^{\prime} \mathrm{N} 97^{\circ} 54^{\prime} \mathrm{W}$ ), to Marceligo Creek near Miranda (now Rosita), Tunky (now Tunki) river, Bambana-Prinzapolka basin, Atlantic versant of Nicaragua (13 $\left.52^{\circ} \mathrm{N} 84^{\circ} 20^{\prime} \mathrm{W}\right)$.

Diagnosis. Species of Pseudoxiphophorus share the following synapomorphies: 1. Post-temporal unbranched (ch. 49-1); 2. Less than 9 dorsal-fin rays (ch. 63-0); 3. Two vertebrae with widened neural spines (ch. 66-2); 4. Ten anal-fin rays in females (ch. 78-1); 5. Subdistal spines on gonopodial ray 3 enlarged ventrally forming a slight elbow along the ventral profile of the ray (ch. 95-1); 6 . Gonopodial ray $4 \mathrm{p}$ as long as ray $5 \mathrm{a}$ (ch. $99-1)$; 7 . Two or more penultimate short segments on gonopodial ray $4 \mathrm{a}$ with a membranous envelope (ch. 100-1); 8. More than four subdistal short segments on gonopodial ray $4 \mathrm{a}$ (ch. 101-1); 9. Keel without axial projection on the posterior ventral surface of anal-fin ray 5 (ch. 105-0); 10. Dorsal-fin melanophores forming two or more rows of discrete spots and anal-fin melanophores extending distally from anal-fin base as streaks in interradial membrane (ch. 129-1); 11. Anal fin with small diffuse dots (ch. 130-2); 12. Presence of a basicaudal spot (ch. 131-1); 13. Basicaudal spot in adults partly or wholly above midlateral line and extending onto caudalfin base (ch. 132-1); 14. Pigment of scale pockets forming a strong reticular network along the sides (ch. 134-1).

\section{Discussion}

Comparisons with previous studies. Some of the phylogenetic results reported above are consistent with the conclusions of previous studies of Poeciliinae. The phylogeny reported in the strict consensus tree (Fig. 1) supports the monophyly of the Cnesterodontini (sensu Lucinda \& Reis, 2005), Gambusiini (sensu Rosen \& Bailey, 1963), and Tomeurini (sensu Rosen \& Bailey, 1963; Parenti \& Rauchenberger, 1989; Lucinda \& Reis, 2005). The monophyly of the Priapichthyini (sensu Lucinda \& Reis, 2005) and Alfarini (sensu Ghedotti, 2000) were not well tested, as each was represented by species in a single genus.

Other results of this study are not consistent with the published taxonomy of Poeciliinae. The Cnesterodontini was not well resolved in the topologies obtained from weighting the unordered multistate characters by the RC (Fig. 2), or from analyzing the data with ordered multistate characters (Fig. 3). Those topologies recovered the Cnesterodontini within Poeciliopsis. The Gambusiini is not monophyletic according to the topology obtained by analyzing the data as ordered-multistate characters (Fig. 3). According to that topology, Brachyrhaphis is not most closely related to the clade Gambusia + Belonesox.

None of the phylogenies recovered in this study support the monophyly of the Poeciliini (sensu Ghedotti 2000; Lucinda $\&$ Reis 2005). In the strict consensus tree (Fig. 1), H. formosa is sister to Quintana and is closely related to Limia and Xiphophorus suggesting that these four genera should be included in Heterandriini. However, the clade of Quintana and $H$. formosa is not well supported by Bremer decay analysis. Further, male specimens of Quintana atrizona were not available for this study, and the data matrix was coded based on published description of this monotypic genus (Hubbs, 1934; Rosen \& Bailey, 1963; Lucinda \& Reis, 2005). In the topology obtained from a posteriori weighting of the unorderedmultistate characters (Fig. 2), H. formosa is most closely related to other genera of Poeciliini (Micropoecilia, Pamphorichthys, Limia, and Poecilia).

The topology obtained from analyzing the dataset as ordered-multistate characters (Fig. 3) supports H. formosa as closely related to the Brachyrhaphini. To verify the phylogenetic relationship between Brachyrhaphis and Heterandria it will be necessary to examine all (or most) of 
the 12 valid species of Brachyrhaphis. If $H$. formosa and Brachyrhaphis are not closely related, the whole Heterandriini could be restricted to $H$. formosa and Brachyrhaphis could be referred to as Brachyrhaphini sensu Lucinda \& Reis (2005).

The strict consensus tree (Fig. 1) suggests that Neoheterandria, Xenophallus, and Scolichthys are closely related. If this relationship is true, Neoheterandria and Xenophallus might be included in the tribe Scolichthyini (rather than the tribe Gambusiini sensu Lucinda \& Reis, 2005). This topology is supported by the analysis of unordered multistate characters with a posteriori weighting (Fig. 2), but not by the analysis of ordered-multistate characters (Fig. 3).

Poeciliopsis was found to be monophyletic in the strict consensus tree (Fig. 1), and is well supported by the Bremer decay analysis, as in Mateos et al. (2002). However, in the other two topologies arising from this study Poeciliopsis was not found to be monophyletic (Figs. 2, 3). Even though the relationships and monophyly of Poeciliopsis are uncertain in all of the analyses Poeciliopsis is not closely related to $H$. formosa and therefore should not be included in Heterandriini.

According to Lucinda \& Reis (2005), Phallichthys should be included in the tribe Girardinini, with Girardinus, Poeciliopsis, Neoheterandria, and Phalloptychus. In the present study specimens of Girardinus and other species of Neoheterandria were not examined but Poeciliopsis and Phallichthys were not found to be closely related. The position of Carlhubbsia varied in this study, but it should be noted the species of Carlhubbsia used here (C. stuarti) differed from that (C. kidderi) used by Lucinda \& Reis (2005).

Gonopodial characters have been proven effective in

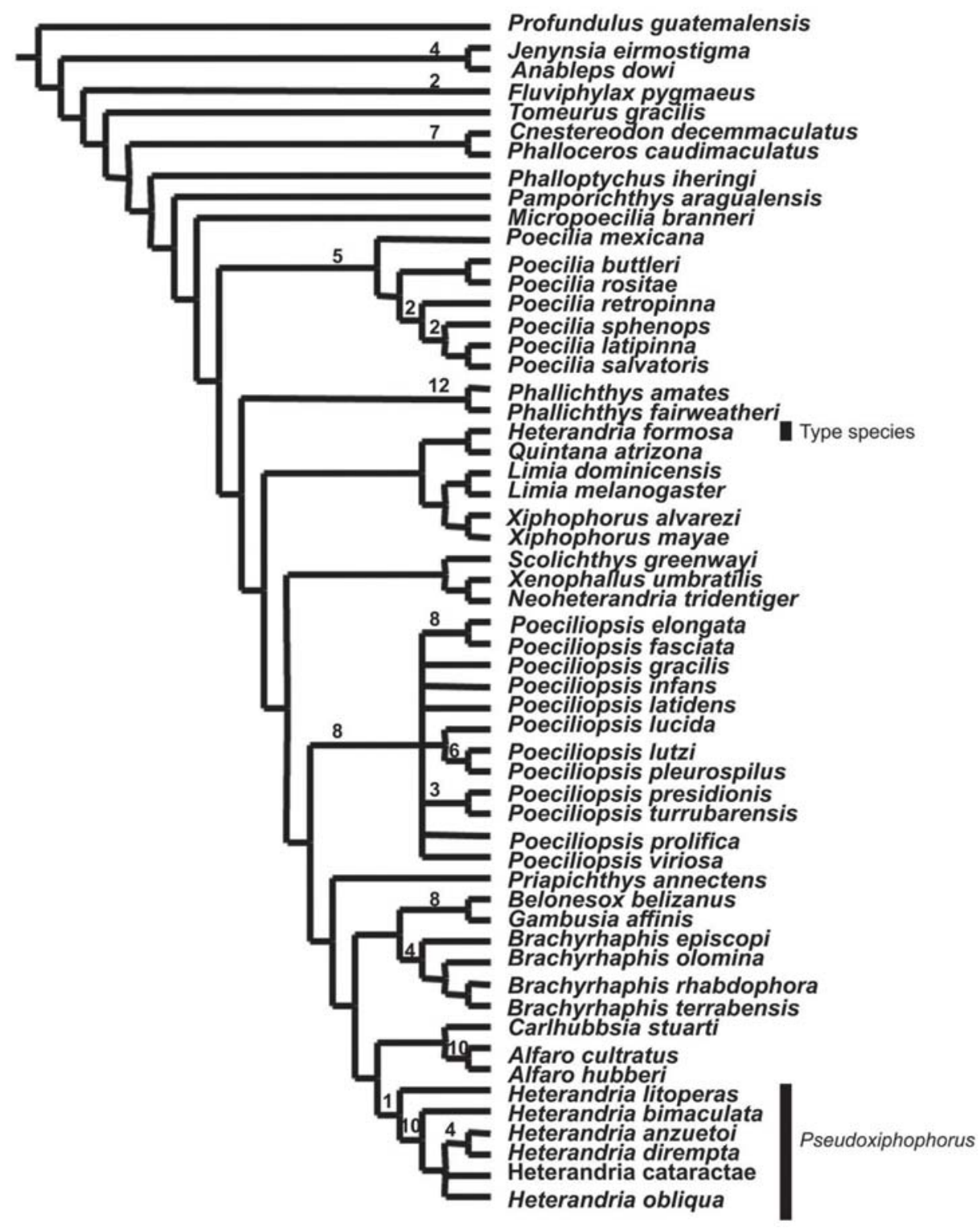

Fig. 1. Strict consensus tree of twelve MP trees with multistate characters analyzed as unordered. Each MP tree of 1,430 steps, $\mathrm{CI}=0.20, \mathrm{RI}=0.48, \mathrm{RC}=0.10$. Numbers indicate Bremer support values. 
structuring aspects of higher level poeciliid classification, and also at the species level. A fully-resolved, generic-level, morphology-based phylogeny of the Poeciliidae awaits complete osteological surveys of the skeletal system for representatives of all the major clades, including taxa missing from the present study (Girardinus Priapella and Xenodexia). Furthermore, it is important to note that the tribe-level designation was originally introduced to differentiate poeciliid groups with characteristic gonopodial structures and distinct geographical distributions (Hubbs, 1924), and not necessarily to diagnose monophyletic groups. Indeed, the traditional tribe-level taxa used in poeciliine systematics do not closely match the results of modern phylogenetic investigations (Rodriguez, 1997; Costa, 1998; Ghedotti, 1998, 2000; Lucinda \& Reis, 2005; Hrbek et al., 2007).

\section{Taxonomy of Heterandria and Heterandriini}

The taxonomic history of Heterandria and Pseudoxiphophorus is complex. Girard (1859) recognized Limia formosa from the coastal plains of southeastern United States (South Carolina to Mexico) on the basis of (among other things) a stout body with low vertebral counts $(17+13=30)$, small teeth in the outer row of each jaw, a relatively tall dorsal fin (having long rays) positioned over the anal fin, and a long alimentary canal (longer than body) with numerous convolutions. This species was subsequently designated as the type of Heterandria Agassiz (1853; see Rosen \& Bailey, 1963; Rosen, 1979), as a distinct genus from the type species of Limia L. vittata (Guichenot, 1853), from Cuba.

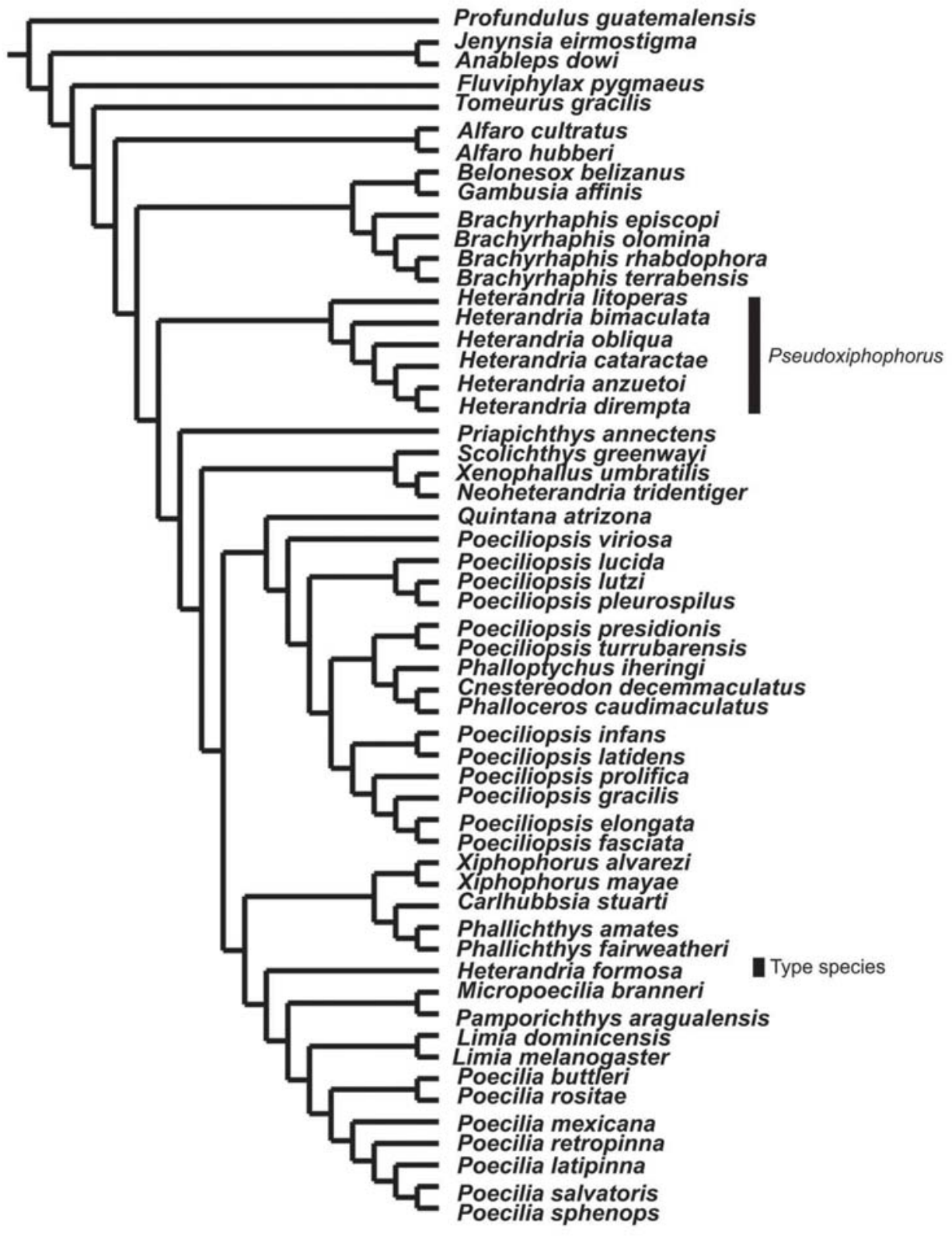

Fig. 2. Single MP tree with multistate characters analyzed as unordered, and with a posteriori weighting using RC (1,444 steps, $\mathrm{CI}=0.20, \mathrm{RI}=0.47, \mathrm{RC}=0.09$ ). 
Bleeker (1860) recognized as Pseudoxiphophorus a species previously described as Xiphophorus bimaculatus (Heckel, 1848) collected from the coastal plains of Vera Cruz, Mexico. Pseudoxiphophorus was described on the basis of having a relatively elongate body (with high vertebral counts; $18+14=32$ ), a flat head, large conical teeth in the outer row of both jaws, many and small gill rakers, a low, long dorsal fin positioned in advance of the anal fin, and a short simple alimentary canal (less than length of body).

Regan (1913) treated Pseudoxiphophorus as a subgenus of Heterandria while Hubbs (1924) recognized Pseudoxiphophorus and Heterandria as distinct genera. Miller (1974) illustrated the gonopodia, gonopodial suspensorium, and color patterns of these two taxa, and also examined morphometric and meristic data. He concluded that the differences between the gonopodia are sufficient to recognize the two genera. Although Rosen \& Bailey (1963) synonymized Pseudoxiphophorus bimaculatus and Heterandria formosa into the genus Heterandria, the description of new Heterandria species caused Rosen (1979) to recognize these taxa as two distinct subgenera. In his review of the genus Heterandria Rosen (1979) added more species to the taxon he referred to as the subgenus Pseudoxiphophorus referring to the assemblage of Heterandria species from Middle America, and limited the subgenus Heterandria to H. formosa. Rosen (1979) also provided a cladogram based on synapomorphies of the described species, area cladograms, and proposed the first identification key for the all species of the subgenus Pseudoxiphophorus.

The monophyly and taxonomic composition of Heterandria has subsequently remained poorly resolved. Whereas Radda

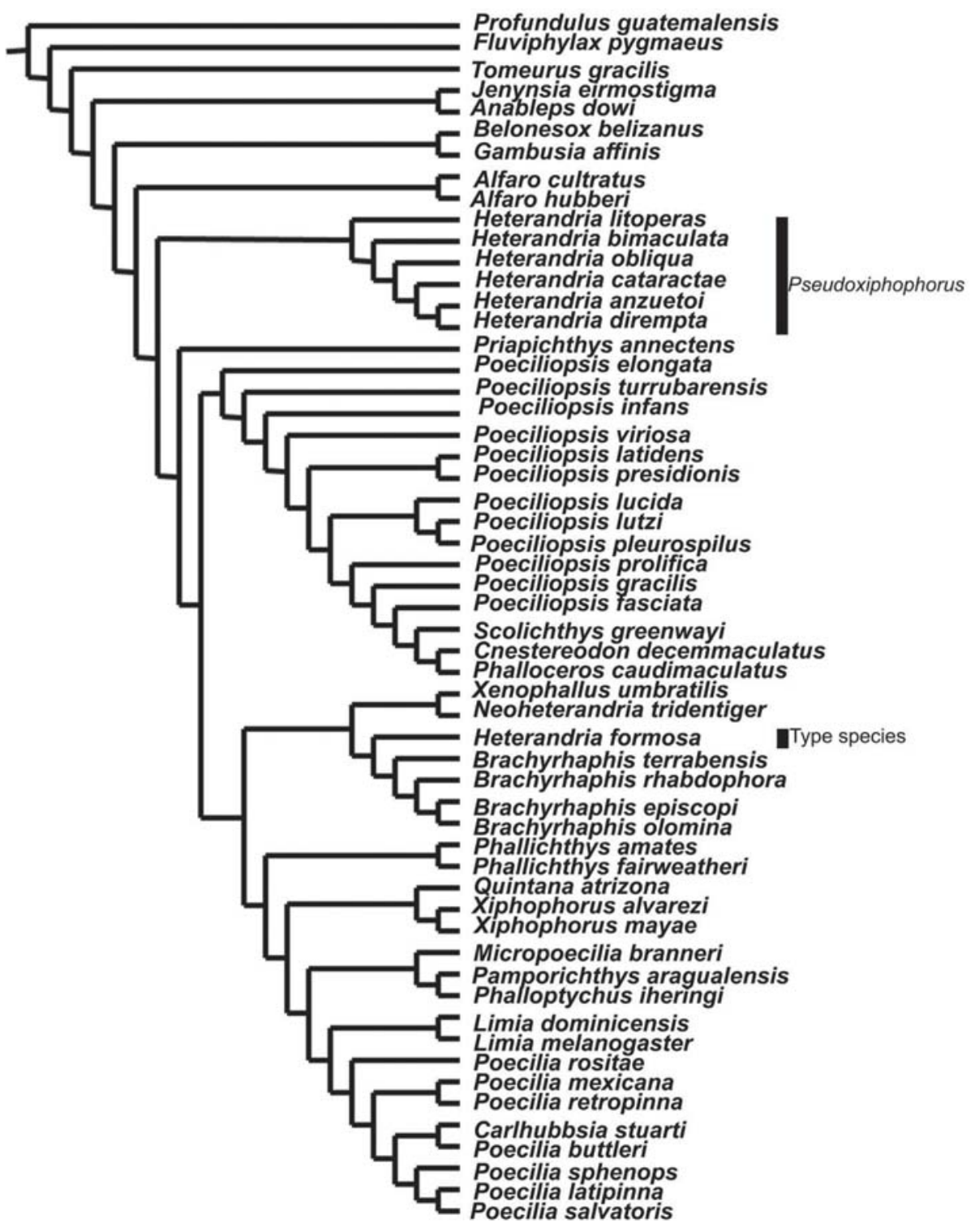

Fig. 3. Single MP cladogram with multistate characters analyzed as ordered, and a posteriori weighting on the RC (1,446 steps, $\mathrm{CI}=0.20, \mathrm{RI}=0.47, \mathrm{RC}=0.09$ ). 
(1985) and Ghedotti (2000) treated Pseudoxiphophorus and Heterandria as different genera, Parenti and Rauchenberger (1989) regarded Pseudoxiphophorus as a subgenus of Heterandria. The most recent systematic treatment of Poeciliinae focused on the tribe Cnesterodontini (Lucinda \& Reis, 2005) and suggested that the Heterandriini should be limited to species of the genus Heterandria sensu Rosen \& Bailey (1963).

More than twenty-seven species have been described since Rosen \& Bailey (1963), and most of the characters traditionally used to diagnose tribe and genus-level taxa are now known to be present in different combinations among species within these higher taxa. In particular, many gonopodial characters have not been corroborated as phylogenetically informative at the tribe or generic-level in the face of increased taxon sampling. Despite more than a century of research, the monophyly and interrelationships of Heterandriini and Heterandria remain uncertain, and a formal taxonomic revision is necessary.

According to the present study, the monophyly of Heterandria sensu Rosen \& Bailey (1963) is not supported by morphological data. However, by design, the character definitions used here were compiled from previous studies on groups other than Heterandriini (Rauchenberger, 1989; Rodriguez, 1997; Costa, 1998; Ghedotti, 1998, 2000; Lucinda $\&$ Reis, 2005). It is therefore not surprising that these characters do a relatively poor job of resolving phylogenetic relationships within the Heterandriini. However, the results of this study do show that Heterandria and Pseudoxiphophorus are not closely related, supporting the hypothesis of Regan (1913), Miller (1974), and Radda (1985) that Pseudoxiphophorus should be recognized as a generic-level taxon. The results of the present study also suggest that Heterandriini should be restricted to $H$. formosa and its closest relatives. The dataset arising from this study is not sufficient to address the phylogenetic relationships of $H$. formosa to other possible members of Heterandriini.

Langerhans et al.(2005) and Hrbek et al.(2007) hypothesized that gonopodial characters are phylogenetically plastic, having evolved multiple times in the Poeciliidae under similar genetic and environmental circumstances. A prediction of such plasticity is that species of Poeciliinae should exhibit many derived changes in the morphology of the gonopodium, a condition that has indeed been observed. Therefore, in light of the high amounts of homoplasy observed in gonopodial characters, accurate tribe-level taxonomic designations of species must await more complete phylogenetic studies at the species level.

\section{Acknowledgements}

We thank R. Arrindell and J. Sparks (AMNH), D. Catania and M. Hoang (CAS), R. Robins (FMNH), P. Chakrabarty and C. McMahan (LSUMZ), C. Lucena and R. Reis (MCP), K. Hartel (MCZ), H. Bart and N. Ríos (TU), R. Barrios, J. Lopez, S. Perez, L. Prado (USAC) for the loan of specimens, M. Barrios, F. Herrera, J. Martinez (CONAP) for logistical support,
N. Arakaki, T. Carvalho, I. Cazan, P. Chakrabarty, D. Ennis, G. Groranova, M. Holder, P. Leberg, V. Madrid, S. Martin, B. Moon, A. Morales, D. Morales, J. Neigel, R. Reis, W. Schmidt, K. Schneider, and R. Wer for valuable discussions and laboratory assistance. This research was supported in part by the UL Lafayette GSO and NSF-DEB 0741450.

\section{Literature Cited}

Agassiz, J. L. R. 1853. Recent researches of Professor Agassiz. American Journal of Science, 16: 134-136.

Albert, J. S. 2001. Species diversity and phylogenetic systematics of American knifefishes (Gymnotiformes, Teleostei). Miscellaneous Publications of the Museum of Zoology, University of Michigan, 190: 1-127.

Albert, J. S. 2009. Phylogenetic character reconstruction. Pp. 1731. In: J. H. Kaas (Ed.). Evolutionary Neuroscience. Elsevier LTD. London. Reprinted from Evolution of Nervous Systems Volume 1.

Albert, J. S. \& W. G. R. Crampton. 2005. Diversity and phylogeny of Neotropical electric fishes (Gymnotiformes). Pp. 360-409. In: T. H. Bullock, C. D. Hopkins, A. N. Popper \& R. R. Fay (Eds.). Electroreception. Springer Handbook of Auditory Research. Springer-Verlag, Berlin.

Albert, J. S. \& D. M. Johnson. 2011. Diversity and evolution of body size in fishes. Evolutionary Biology, 1-17.

Albert, J. S., P. Petry \& R. E. Reis. 2011. Major biogeographic and phylogenetic patterns. Pp. 21-58. In: J. S. Albert \& R. E. Reis (Eds.). Historical Biogeography of Neotropical Freshwater Fishes. University of California Press, Berkeley.

Ane, C. \& M. J. Sanderson. 2005. Missing the forest for the trees: Phylogenetic compression and its implications for inferring complex evolutionary histories. Systematic Biology, 54:146-157.

Bleeker, P. 1860. Conspectus systematics Cyprinorum Natuurkundig Tijdschrift voor Nederlandsch Indie, 20: 421-441.

Borrowsky, R. L., M. McClelland, R. Cheng \& J. Welsch. 1995. Arbitrarily primed DNA fingerprinting for phylogenetic reconstruction in vertebrates: The Xiphophorus model. Molecular Biology and Evolution, 12: 1022-1032.

Breder, C. M. Jr. \& D. E. Rosen. 1966. Modes of Reproduction in Fishes. New York: American Museum of Natural History Press.

Bremer, K. 1988. The limits of amino acid sequence data in angiosperm phylogenetic reconstruction. Evolution 42: 795-803.

Bryant, D. 2003. A classification of consensus methods for phylogenetics. Pp: 163-184. In: Bioconsensus, Ser. DIMACS Series in Discrete Mathematics and Theoretical Computer Science (Org.). 2002. New York: AMS Press, 61.

Campo, D., G. Machado-Schiaffino, J. Perez \& E. Garcia-Vazquez. 2007. Phylogeny of the genus Merluccius based on mitochondrial and nuclear genes. Gene, 406: 171-179.

Costa, W. J. E. M. 1996. Relationships, monophyly and three new species of the neotropical miniature poeciliid genus Fluviphylax (Cyprinodontiformes: Cyprinodontoidei). Ichthyological Exploration of Freshwaters, 7: 111-130.

Costa, W. J. E. M. 1998. Phylogeny and classification of the Cyprinodontiformes (Euteleostei: Atherinomorpha): A reappraisal. Pp. 537-560. In: L. R. Malabarba, R. E. Reis, R. P. Vari, Z. M. S. Lucena \& C. A. S. Lucena (Eds.). Phylogeny and Classification of Neotropical Fishes. Porto Alegre, Brazil: Edipucrs.

Farris, J. S. 1989. The retention index and the rescaled consistency index. Cladistics, 5: 417-419. 
Fricke, R. \& W. N. Eschmeyer. 2011 or 2012?.A guide of Fish Collections in the Catalog of Fishes database. On line version of http:// www.fishbase.org/References/FBRefSummary.php?id=86697

Ghedotti, M. J. 1998. Phylogeny and classification of the Anablepidae (Teleostei: Cyprinodontiformes). Pp. 561-582. In: L. R. Malabarba, R. E. Reis, R. P. Vari, Z. M. Lucena \& C. A. S. Lucena. (Eds.). Phylogeny and Classification of Neotropical Fishes. Porto Alegre: Edipucrs.

Ghedotti, M. J. 2000. Phylogenetic analysis and taxonomy of the poecilioid fishes (Teleostei: Cyprinodontiformes). Zoological Journal of the Linnean Society, 130: 1-53.

Girard, C. F. 1859. Ichthyological notices. Proceedings of the Academy of Natural Sciences of Philadelphia, 11: 113-122.

Goloboff, P. 1999a. Analyzing large data sets in reasonable times: solutions for composite optima. Cladistics, 15: 415-428.

Goloboff, P. 1999b. NONA (NO NAME). Version 2. Tucuman, Argentina.

Goloboff, P., J. Farris \& K. Nixon. 2008. TNT, a free program for phylogenetic analysis. Cladistics, 24: 774-786.

Gosline, W. A. 1949. The sensory canals of the head in some cyprinodont fishes, with particular reference to the genus Fundulus. Occasional Papers of the Museum of Zoology, University of Michigan, 339: 1-519.

Greenfield, D. 1985. Review of the Gambusia yucatana complex (Pisces: Poeciliidae) of Mexico and Central America. Copeia, 1985: 368-378.

Guichenot, A. 1853. Zoologie. Poissons. Pp. 1-206. In: Ramon de la Sagra, D. Histoire physique, politique et naturelle de l'Ile de Cuba (Org.). Paris, Vol. 2.

Gutierrez-Rodriguez, C., M. R. Morris, N. S. Dubois \& K. de Queiroz. 2007a. Genetic variation and phylogeography of the swordtail fish Xiphophorus cortezi (Cyprinodontiformes, Poeciliidae). Molecular Phylogenetics and Evolution, 43: 111-123.

Gutierrez-Rodriguez, C., A. E. Shearer, M. R. Morris \& K. de Queiroz. 2007b. Phylogeography and monophyly of the swordtail fish species Xiphophorus birchmanni (Cyprinodontiformes, Poeciliidae). The Norwegian Academy of Science and Letters, Zoologica Scripta, 37: 129-139.

Heckel, J. J. 1848. Eine neue Gattung von Poecilien mit rochenartigem Anklammerungs-Organe. Sitzungsberichte der Kaiserlichen Akkademie der Wissenschaften. MathematischNaturwissenschaftliche. Classe V, 1: 289-303.

Howell Rivero, L. \& C. L. Hubbs. 1936. Studies of the fishes of the order Cyprinodontes. XV. The characters and relationships of Furcipenis huberi and Alfaro cultratus. Occasional Papers of the Museum of Zoology, University of Michigan, 339: 1-11.

Hrbek, T., J. Seckinger \& A. Meyer. 2007. A phylogenetic and biogeographic perspective on the evolution of poeciliid fishes. Molecular Phylogenetics and Evolution, 43: 986-998.

Hubbs, C. L. 1924. Studies of the fishes of the order Cyprinodontes. Miscellaneous Publications of the Museum of Zoology, University of Michigan, 16: 1-86.

Hubbs, C. L. 1926. Studies of the fishes of the order Cyprinodontes. VI. Miscellaneous Publications of the Museum of Zoology, University of Michigan 18: 1-86.

Hubbs, C. L. 1931. Studies of the fishes of the order Cyprinodontes. IX. A new and primitive genus of Poeciliidae from Central America. Occasional Papers of the Museum of Zoology, University of Michigan, 230: 1-3.

Hubbs, C. L. 1934. Studies of the fishes of the order Cyprinodontes. XIII. Quintana atrizona a new poeciliid. Occasional Papers of the Museum of Zoology, University of Michigan, 301: 1-14.
Huber, J. H. 1999. Updates to the phylogeny and systematics of the African lampeye schooling cyprinodonts (Cyprinodontiformes: Aplocheilichthyinae). Cybium, 23: 153-177.

Kallman, K. D., R. B. Walter, D. C. Morizot \& S. Kazianis. 2004. Two new species of Xiphophorus (Poeciliidae) from the Isthmus of Tehuantepec, Oaxaca, Mexico, with a discussion of the distribution of $X$. clemenciae clade. American Museum Novitates, 3441: 1-34.

Kluge, A. J. 2001. Philosophical conjectures and their refutation. Systematic Biology, 50: 322-330.

Kulkarni, M. \& B. Moret. 2005. Consensus Methods Using Phylogenetic Databases. IEEE Computational Systems Bioinformatics Conference. Workshops CSBW'05.

Langerhans, R. B., C. A. Layman \& T. J. DeWitt. 2005. Male genital size reflects a tradeoff between attracting mates and avoiding predators in two livebearing fish species. Proceedings of the Natural Academy of Sciences, 102: 7618-7623.

Leberg, P. L. \& B. D. Firmin. 2008. Role of inbreeding depression and purging in captive breeding and restoration programmes. Molecular Ecology, 17: 334-343.

Leviton, A. E., R. H. Gibbs, E. Heal \& C. E. Dawson. 1985. Standards in herpetology and ichthyology: Part I. Standard symbolic codes for institutional resource collections in herpetology and ichthyology. Copeia, 1985: 802-832.

Lucinda, P. H. F. 2003. Family Poeciliidae (Livebearers). Pp. 555581. In: R. R. Reis, S. O. Kullander \& C. J. Ferraris Jr. (Eds.). Checklist of the Freshwater Fishes of South and Central America. Porto Alegre, Edipucrs.

Lucinda, P. H. F. 2005a. Systematics of the genus Cnesterodon Garman, 1895. (Cyprinodontiformes: Poeciliidae: Poeciliinae). Neotropical Ichthyology, 3: 259-270.

Lucinda, P. H. F. 2005b. Systematics of the genus Phalloptychus Eigenmann, 1907 (Cyprinodontiformes: Poeciliidae: Poeciliinae). Neotropical Ichthyology, 3: 373-382.

Lucinda, P. H. F. 2008. Systematics and biogeography of the genus Phalloceros Eigenmann, 1907 (Cyprinodontiformes: Poeciliidae: Poeciliinae), with the description of twenty-one new species. Neotropical Ichthyology, 6: 113-158.

Lucinda, P. H. F., M. J. Ghedotti \& W. J. Graca. 2006. A new Jenynsia species (Teleostei, Cyprinodontiformes, Anablepidae) from Southern Brazil and its phylogenetic position. Copeia, 2006: 613-622.

Lucinda, P. H. F. \& R. E. Reis. 2005. Systematics of the subfamily Poeciliinae Bonaparte (Cyprinodontiformes: Poeciliidae), with an emphasis on the tribe Cnesterodontini Hubbs. Neotropical Ichthyology, 3: 1-60.

Lucinda, P. H. F., R. S. Rosa \& R. E. Reis. 2005. Systematics and biogeography of the genus Phallotorynus Henn, 1916 (Cyprinodontiformes, Poeciliidae, Poeciliinae), with description of three new species. Copeia, 2005: 608-630.

Maddison, W. P. \& D. R. Maddison. 1993. MacClade Analysis of Phylogeny and Character Evolution. Version 3.03, Sunderland, Sunderland Associates, Inc. Massachusetts.

Maddison, W. P. \& D. R. Maddison. 2009. Mesquite: a modular system for evolutionary analysis. Version 2.72. http:// mesquiteproject.org

Marcus, J. M. \& A. R. McCune. 1999. Ontogeny and phylogeny in the northern swordtail clade of Xiphophorus. Systematic Biology 48: 491-522.

Martin, S. B., A. T. Hitch, K. M. Purcell, P. L. Klerks \& P. L. Leberg. 2009. Life history variation along a salinity gradient in coastal marshes. Aquatic Biology, 8: 15-28. 
Mateos, M., O. I. Sanjur \& R. C. Vrijenhoek. 2002. Historical biogeography of the livebearing fish genus Poeciliopsis (Poeciliidae: Cyprinodontiformes). Evolution, 56: 972-984.

Meredith, R. W., M. N. Pires \& D. N. Reznick. 2010. Molecular phylogenetic relationships and the evolution of the placenta in Poecilia (Micropoecilia) Poeciliidae: Cyprinodontiformes). Molecular Phylogenetics and Evolution, 55: 631-639.

Meyer, A., J. M. Morrissey \& M. Schartl. 1994. Recurrent origin of a sexual selected trait in Xiphophorus fishes inferred from molecular phylogeny. Nature, 386: 539-542.

Miller, R. R. 1948. The cyprinodont fishes of the Death Valley system of eastern California and southwestern Nevada. Miscellaneous Publications of the Museum of Zoology, University of Michigan, 68: 1-155.

Miller, R. R. 1955. A systematic review of the Middle American fishes of the genus Profundulus. Miscellaneous Publications. Museum of Zoology, University of Michigan, 92: 1-63.

Miller, R. R. 1974. Mexican species of the genus Heterandria Subgenus Pseudoxiphophorus (Pisces: Poeciliidae). Transactions of the San Diego Society of Natural History, 17: 235-250.

Morris, M., K. Queiroz \& D. Morizot. 2001. Phylogenetic relationships among populations of northern swordtails (Xiphophorus) as inferred from allozyme data. Copeia, 2001: 65-81.

Nixon, K. C. 1999-2002. Winclada ver. 1.00.08. Published by the author, Ithaca, NY, USA.

Parenti, L. R. 1981. A phylogenetic and biogeographical analysis of Cyprinodontiform fishes (Teleostei, Atherinomorpha). Bulletin of the American Museum of Natural History, 168: 341-557.

Parenti, L. R. \& M. Rauchenberger. 1989. Systematic overview of the Poeciliines. Pp. 3-12. In: G. K. Meffe \& F. F. Snelson, Jr. (Eds.). Ecology and Evolution of livebearing fishes (Poeciliidae). Prentice Hall Advanced Reference Series. Physical and Life Sciences.

Patterson, C. 1975. The braincase of pholidiophorid and leptolepid fishes, with review of the actinopterygian braincase. Philosophical Transactions of the Royal Society of London. Series B: Biological Sciences, 269: 275-279.

Pires, M. N., J. Arendt \& D. N. Reznick. 2010. The evolution of placentas and superfetation in the fish genus Poecilia (Cyprinodontiformes: Poeciliidae: subgenera Micropoecilia and Acanthophacelus). Biological Journal of the Linnean Society, 99: 784-796.

Pollux, B. J. A., M. N. Pires, A. I. Banet \& D. N. Reznick. 2009. Evolution of placentas in the fish family Poeciliidae: An empirical study of macroevolution. Annual Review of Ecology, Evolution and Systematics, 40: 271-289.

Purcell, K. M., A. T. Hitch, P. L. Klerks \& P. L. Leberg. 2008. Adaptation as a potential response to sea-level rise: a genetic basis for salinity tolerance in populations of a coastal marsh fish. Evolutionary Applications, 1: 155-160.

Radda, A. C. 1985. Revalidieserung der Gattung Pseudoxiphophorus Bleeker 1860 (Poeciliidae: Osteichthyes). Sonderdruck aus Aquaria, 32: 126-128.

Rauchenberger, M. 1989. Systematics and biogeography of the genus Gambusia (Cyprinodontiformes: Poeciliidae). American Museum Novitates, 2951: 1-74.

Rauchenberger, M. 1990. Monophyly and geography of the río Panuco basin swordtails (Genus Xiphophorus) with descriptions of four new species. American Museum Novitates, 2975: 1-41.

Regan, C. T. 1913. A revision of the Cyprinodont fishes of the subfamily Poeciliinae. Proceedings of the Zoological Society, 5: 977-1019.
Reznick, D., T. Hrbek, S. Caura, J. de Greef \& D. Roff. 2007. Life history of Xenodexia ctenolepis: implications for life history evolution in the family Poeciliidae. Biological Journal of the Linnean Society, 92: 77-85.

Rodriguez, C. M. 1997. Phylogenetic analysis of the tribe Poeciliini (Cyprinodontiformes, Poeciliidae). Copeia, 1997: 663-679.

Rosa, R. S. \& W. J. E. M. Costa. 1993. Systematic revision of the genus Cnesterodon (Cyprinodontiformes: Poeciliidae). Copeia, 1993: 696-708.

Rosen, D. E. 1967. New Poeciliid fishes from Guatemala, with comments on the origin of some South and Central American forms. American Museum Novitates, 2303: 1-15.

Rosen, D. E. 1979. Fishes from the uplands and intermontane basins from Guatemala: revisionary studies of comparative geography. Bulletin of the American Museum of Natural History, 162: 269-375.

Rosen, D. E. \& R. M. Bailey. 1959. Middle-American poeciliid fishes of the genera Carlhubbsia and Phallichthys, with descriptions of two new species. Zoologica, 44: 1-43.

Rosen, D. E. \& R. M. Bailey. 1963. The Poeciliid fishes (Cyprinodontiformes) their structure, zoogeography and systematic. Bulletin of the American Museum of Natural History, 126: 1-176.

Rosen, D. E. \& M. Gordon. 1951. Genetics of species differences in the morphology of the male genitalia of xiphophorin fishes. Bulletin of the American Museum of Natural History, 95: 409-464.

Rosen, D. E. \& M. Gordon. 1953. Functional anatomy and evolution of male genitalia in Poeciliid fishes. Zoologica, 38: 1-47.

Rosen, D. E. \& K. D. Kallman. 1969. A new fish of the genus Xiphophorus from Guatemala, with remarks on the taxonomy of endemic forms. American Museum Novitates, 2379: 1-29.

Rosen, D. E. \& J. R. Mendelson. 1960. The sensory canals of the head in poeciliid fishes (Cyprinodontiformes), with reference to dentitional types. Copeia, 1960: 203-210.

Sorenson, M. D. 1999. TreeRot, version 2. Boston University, Boston, MA.

Spencer, C. C., C. A. Chlan, J. E. Neigel, K. T. Scribner, M. C. Wooten \& P. L. Leberg. 1999. Polymorphic microsatellite markers in the western mosquitofish, Gambusia affinis. Molecular Ecology, 8: 157-158.

Spencer, C. C., J. E. Neigel \& P. L. Leberg. 2000. Experimental evaluation of the usefulness of microsatellite DNA for detecting demographic bottlenecks. Molecular Ecology, 9: 1517-1528.

Swofford, D. L. 1993. PAUP: Phylogenetic Analysis Using Parsimony. Version 3. 1. 1. Computer program distributed by the Illinois Natural History Survey, Champaign, Illinois.

Swofford, D. L. 2002. PAUP*. Phylogenetic analysis using parsimony (*and other methods). Sinauer Associates, Sunderland MA.

Taylor, W. R. \& G. C. van Dyke. 1985. Revised procedures for staining and clearing small fishes and other vertebrates for bone and cartilage study. Cybium, 9: 107-119.

Weitzman, S. 1974. Osteology and evolutionary relationships of Sternoptychidae, with a new classification of stomiatoid families. Bulletin of the American Museum of Natural History, 153: 327-478.

Wourms, J. P. 1981. Viviparity: the maternal-fetal relationship in fishes. American Zoologist, 21: 473-515.

Submitted July 10, 2011

Accepted February 7, 2012

Published March 30, 2012 
Appendix 1. Material examined included in the phylogenetic analyses.

Outgroups. Anablepidae: Anableps dowi: TU 39076, Mexico, Oaxaca, Tehuantepec, río Tehuantepec, río Tehuantepec, $\mathrm{N}=10$. Jenynsia, eirmostigna: MCP 22045, Brazil, Santa Catarina, Uruguay, río Cachoeira on road from Bom Jardim to Santa Barbara, ca. $5.1 \mathrm{~km}$ a N of Bom Jardim da Serra, 28 18'26”S $49^{\circ} 37^{\prime} 02^{\prime \prime} \mathrm{W}$, $\mathrm{N}=8$. Profundulidae: Profundulus guatemalensis: USAC 769, Guatemala, Escuintla, Nueva Concepcion, $\mathrm{N}=2$. Profundulus labialis: LSUMZ 14328, Guatemala, Baja Verapaz, río San Jeronimo, río Salama, río Chixoy. N=2.

Ingroups (Poeciliinae). Alfaro huberi: LSUMZ 14335, Guatemala, río Trincheras, Aldea Campo Dos $214 \mathrm{~m}$, $15^{\circ} 23.1^{\prime} 45.2^{\prime \prime S} 89^{\circ} 02^{\prime} 41.3$ ”'W, N = 5. USAC 150, Guatemala, Izabal, Los Amates, aldea Campo Dos, río Motagua, $\mathrm{N}=4$. Alfaro cultratus: TU 24927, Costa Rica, Heredia $1 \mathrm{mi}$. W Chilamate, trib. río Sarapiqui, río San Juan, N=30. Belonesox belizanus: SU 25076, Costa Rica, Guanacaste, Costa Rica and Nicaraguan border, Panamerican Hwy, río Sapoa, lago de Nicaragua, $\mathrm{N}=6$. Brachyrhaphis episcopi: SU 50303, Panama, streams near Obispo Station, Canal Zone, Panama, N = 30. Brachyrhaphis olomina: TU 24997, Costa Rica, Puntarenas, 9 km NW Esparta, Panamerican Hwy, río Ciruelitas, río Ciruelitas, $\mathrm{N}=31$. Brachyrhaphis rhabdophora: TU 84483, Costa Rica, San Jose, 6.2 mi. S San Isidro del General, río Peje, tributary río Pacuare, río Grande de Terraba, $\mathrm{N}=73$. Brachyrhaphis terrabensis: AMNH 20503, Panama, Chiquiri, 3 mi. W Cerro Punta, N = 2. SU 32204, Panama, Boquete, Chirique, elev. $3800 \mathrm{ft}, \mathrm{N}=38$. TU 25147, Costa Rica, San Jose, $11 \mathrm{~km}$ SE San Isidro del General, trib. río General, río Grande de Terraba, $\mathrm{N}=4$. Carlhubbsia stuarti: LSUMZ 14333, Guatemala, Izabal, El Estor, N = 3. USAC 1960, Guatemala, Izabal, El Estor, lago de Izabal, N = 10. USAC 204, Guatemala, Izabal, río Dulce, El Golfete, $\mathrm{N}=30$. Cnesterodon decemmaculatus: $\mathrm{MCP}$ 35215, Brazil, Rio Grande do Sul, rio Uruguay basin, arroio Garupá, on road from Quarai to Harmonia, ca. 33km NE Quaraí, 3009'45”S $56^{\circ} 14^{\prime} 08^{\prime \prime} \mathrm{W}, \mathrm{N}=6$. Fluviphylax pygmaeus: MCP 38830, Brazil, Amazonas, Madeira Igarapé, ca. $68 \mathrm{~km}$ E of rio Madeira on Hwy. Transamazonica, $07^{\circ} 43^{\prime} 58^{\prime}$ 'S 62 $29^{\circ}$ '40”'W, N = 3. Gambusia affinis: TU 114758, United States, Texas, Hardin, Neches River and Pine Island Bayou at point of land between confluence Neches River, N $=50$. Heterandria anzuetoi: LSUMZ 14332, Guatemala, quebrada Marajuma, río Morazan $1028 \mathrm{ft}$., 1455'15.1'N 9006’00”'W, N = 8. Heterandria bimaculata: AMNH 36338, Guatemala, Alta Verapaz, Chisec, río San Simon, $6 \mathrm{~km}$ W Chisec, río La Pasion, $\mathrm{N}=20$. CAS 78795, Guatemala, Izabal, Los Amates, río Motagua, $\mathrm{N}=37$. SU 772, Mexico, Veracruz, Orizaba, río Blanco, $\mathrm{N}=37$. TU 84879, Mexico, Veracruz, 9 mi. S jct Hwys 150 and 180 on Hwy 180 laguna Mandinga Grande, N=7. TU 183396, México, Oaxaca, 40.4 mi. N Union Hidalgo, Hwy 185, río Maloteugo, río Coatzacoalcos, $\mathrm{N}=14$. Heterandria cataractae: LSUMZ 14338, Guatemala, río Sachicha, río Chixoy, río Salinas, $\mathrm{N}=10$. Heterandria dirempta: LSUMZ 14337, Guatemala, río Semococh 195 m, 1543'16.2”N $89^{\circ} 56^{\prime 26.5}$ ”W, río Chajmaic, río Sebol, río de la Pasion, río Usumacinta system, $\mathrm{N}=25$. Heterandria formosa: TU 173285 , United States, Alabama, Washington, flood pools along west side of US Hwy 43, just S of Tombigbee River, $N=27$. TU 24002, United States, Louisiana, Terrabonne, Willow Lake, on W end of Lake Penchant, Gulf of Mexico, N = 69. TU 183460, United States, Louisiana, St. Charles Bayou, La Branche at mouth of Bayou Traverse, 2.1 air mi. S of I10 crossing Bayou LaBranche Lake
Pontchartrain, $\mathrm{N}=74$. TU 198116, United States, Louisiana, Jefferson Barataria Preserve, pools in marsh Mississippi, $\mathrm{N}=18$. TU 11446, United States, Louisiana, St. Tammany, pool 300 yards from north shore of Lake Pontchartrain, $0.5 \mathrm{mi}$. E of Madisonville Bridge, $\mathrm{N}=80$. TU 44904, United States, Louisiana, St. Charles Bonnet Carre Spillway, right on Hwy 61 bridge Mississippi, N = 26. TU 172485, United States, Alabama, Washington, flood pools along west side of US Hwy 43, just S of Tombigbee River, $N=6$. TU 178234, United States, Alabama, Washington, flood pools along west side of US Hwy 43, just $\mathrm{S}$ of Tombigbee River, $\mathrm{N}=8$. TU 20735, United States, Florida, Pasco, Hillsboro River, 3 mi. S of Zephyrhills Hwy 39, Tampa Bay, N = 82. TU 32177, United States, Florida, Calhoun, Simmons Creek, $4.2 \mathrm{mi}$. N of Blountstown, Apalachicola River, $N=26$. TU 36138, United States, Florida, Broward, 36 mi. NW of Miami in ditch on SW side of US Hwy 27, $\mathrm{N}=24$. TU 105550, United States, Florida, Walton Black Creek 5.5 mi. SE of Freeport, Choctawhatchee River, $\mathrm{N}=38$. TU 102550, United States, Florida, Alachua, Lochlossa Creek, $1 \mathrm{mi}$. SE of Grove Park Hwy 20 at St. Johns River, N = 43. TU 102013, United States, Florida, Levy, Little Waccasassa River at US Hwy alternate 27 and jet with Hwy 339 Waccasassa River, $\mathrm{N}=200$. TU 124325, United States, Florida, Walton Black creek 5.5 mi. SE of Freeport Choctawhatchee River, $\mathrm{N}=55$. UF 57, United States, Florida, Alachua, Orange Lake $29^{\circ} 27^{\prime} 41.0^{\prime \prime} \mathrm{N} 82^{\circ} 10^{\prime} 26.0^{\prime \prime} \mathrm{W}, \mathrm{N}=18$. UF 4979, United States, Florida, Suwannee Ichetucknee Springs, upper 0.25 mi. run, $29^{\circ} 59^{\prime} 08^{\prime} \mathrm{N} 82^{\circ} 45^{\prime} 32^{\prime} \mathrm{W}, \mathrm{N}=154$. Heterandria litoperas: USAC 1813, Guatemala, Alta Verapaz, Coban, río Cahabon, $\mathrm{N}=10$. USAC 20, Guatemala, Alta Verapaz, Panzos, río Secoquito, N = 4. LSUMZ 14331, Guatemala, Izabal, Polochic, río Cahabon $5118 \mathrm{ft} ., 15^{\circ} 17^{\prime} 21.9^{\prime \prime} \mathrm{N} 90^{\circ} 18^{\prime} 05.2^{\prime \prime} \mathrm{W}, \mathrm{N}=13$. Heterandria obliqua: USAC 1784, Guatemala, Alta Verapaz, Coban, trib. río Dolores, $\mathrm{N}=20$. LSUMZ 14339, Guatemala, trib. río Dolores, $15^{\circ} 42^{\prime} 12.7$ ”N 90²4’54.6”W, río Dolores, río Icvolay, río Chixoy, río Salinas, $N=9$. Limia dominicensis: MCZ 30756, Haiti, Lake Assuei, $\mathrm{N}=7$. Limia melanogaster: $\mathrm{MCZ}$ 58314, Jamaica, Bluefields Rivulet, Waterwheel, first major stream $3 \mathrm{mi}$. of Bluefields Rivulet, $\mathrm{N}=33$. Micropoecilia branneri: $\mathrm{MCP} 22040$, Brazil, Paraná, Amazonas, Igarapé Apeu on road Belém/Brasília (BR-010), $1^{\circ} 18^{\prime} 06^{\prime} \mathrm{S} 47^{\circ} 59^{\prime} 11^{\prime} \mathrm{W}$, trib. rio Guamá, $\mathrm{N}=1$ of $1 \mathrm{c} \& \mathrm{~s}$. Neoheterandria tridentiger: SU 24775, Panama, Canal Zone, Chares R. Maddem Dam, $\mathrm{N}=56$. Xenophallus umbratilis: TU 186285, Costa Rica, Puntarenas, E of Puntarenas, just off Panamerican Hwy río Naranjo, río Naranjo, $\mathrm{N}=9$. Pamphorichthys araguaiensis: MCP 40919, Brazil, Tocantins, Canal Chamada, na area do PFI São João, settlement Córrego da Prata, 10²0'15"S $48^{\circ} 22^{\prime} 33^{\prime \prime} \mathrm{W}, \mathrm{N}=8$. Phallichthys amates: LSUMZ 14334, Guatemala, Izabal, Puerto Barrios, río Machacas, $23 \mathrm{~m}$, $15^{\circ} 45^{\prime} 48.0^{\prime \prime} \mathrm{N} 88^{\circ} 31$ '51.7'W, $\mathrm{N}=16$. CAS 78736, Costa Rica, Turrialba, open pond, $\mathrm{N}=37$. Phallichthys fairweatheri: LSUMZ 14504, Guatemala, arroyo El Jute $149 \mathrm{~m}, 15^{\circ} 58^{\prime} 52.8^{\prime \prime N}$ 90²6'33.8”W, río Chixoy, río Salinas, $\mathrm{N}=7$. AMNH 25168, Guatemala, Peten, arroyo Yaxtunila, $8 \mathrm{~km}$ from río de la Pasion, $26-30.30^{\circ} \mathrm{N} 90-16.40^{\circ} \mathrm{W}, \mathrm{N}=4$. USAC 1797, Guatemala, Alta Verapaz, Chisec, pantano Rubelpuy near Chiquibul, $\mathrm{N}=2$. Phalloceros buckupi: SU 64230, Brazil, Paraná, Estrada do Mar, río de Vila, $9.5 \mathrm{~km}$ from Paranaguá, $\mathrm{N}=39$. MCP 40527, Brazil, Rio Grande do Sul, bridge on rio Cadeia, entrance to Jacaré, vila Cristo Rei, 29²9'50”S 5058'06”W, N = 8. Phalloptychus iheringii: MCP 11054, Brazil, Santa Catarina, río Tubarao next to Caines, and near Campo Verde, $28^{\circ} 31^{\prime} \mathrm{S} 48^{\circ} 49^{\prime} \mathrm{W}, \mathrm{N}=8$. Poecilia buttleri: USAC 786, Guatemala, Escuintla, Guanagazapan, bridge on river, $\mathrm{N}=6$. Poecilia latipinna: LSUMZ 14790, United States, 
Louisiana, St. Charles Bayou at bayou boat launch off guide levee, Labranche wetlands, Bayou Trepanier, $\mathrm{N}=9$. Poecilia mexicana: TU 189832, Costa Rica, Puntarenas, $5 \mathrm{~km} \mathrm{SW}$ of San Isidro, trib. río General at Palma, río Pacuare, río Grande de Terraba, $\mathrm{N}=23$. Poecilia rositae: USAC 1822, Guatemala, Alta Verapaz, Lanquin, Semuc Champey, $\mathrm{N}=30$. Poecilia salvatoris: USAC 762, Guatemala, Santa Rosa, Taxisco, La Providencia, río Tejutla 4 km S toward hacienda Yotel, $\mathrm{N}=6$. Poecilia sphenops: CAS 78721, Guatemala, Algeria, río Motagua, $\mathrm{N}=60$. Poecilia retropinna: $\mathrm{TU}$ 186602, Costa Rica, Puntarenas, $1 \mathrm{~km} \mathrm{~S}$ of Coto, Independiente along Golfito Road, río Coto Colorado, $\mathrm{N}=29$. Poecilia rositae: LSUMZ 14507, Guatemala, quebrada El Arco, río Cahabon, N = 7. Poeciliopsis elongata: AMNH 28607, Panama, Panama, Old Panama, $\mathrm{N}=6$. TU 25153, Costa Rica, San Jose, $11 \mathrm{~km}$ SE San Isidro del General, trib. río General, río Grande de Terraba, $\mathrm{N}=23$. Poeciliopsis fasciata: TU 39095, México, Oaxaca, 7.3 km N Juchitan, río Los Perros, $\mathrm{N}=700$. Poeciolopsis gracilis: AMNH 31546, Guatemala, Jutiapa-Santa Rosa, río los Esclavos at Los Cerritos, $\mathrm{N}=8$. TU 84966, México, Veracruz, 9 mi. SE Paso de Orejas, Hwy 140 trib. río de la Antigua, río Antigua, $\mathrm{N}=38$. USAC 912, Guatemala, Santa Rosa, Taxisco, Monterico, $\mathrm{N}=7$. USAC 838, Guatemala, Escuintla, laguna Calderas, $\mathrm{N}=5$. Poeciliopsis infans: $\mathrm{SU} 47631$, México, Jalisco, Guadalajara, 12 mi. S of Guadalajara, Hwy 35, el canal de la Presa de Logado, N=28. TU 31924, México, Michoacan, La Estancia de Villa Jimenez, 14.3 mi. NE Zacapu, lago de Presa, $\mathrm{N}=54$. Poeciliopsis latidens: CAS 54406, México, Sinaloa, Culiacan, fresh muddy water, $\mathrm{N}=28$. Poeciliopsis lucida: $\mathrm{SU}$ 18548, Mexico, Sonora, río Guirocoba, 33 mi. of Alamos, $\mathrm{N}=90$. Poeciliopsis lutzi: CAS 78767, Guatemala, río Motagua, $\mathrm{N}=63$. Poeciliopsis pleurospilus: LSUMZ 14329, Guatemala, Baja Verapaz, Salamá, río San Jerónimo, río Salamá, río Chixoy, $15^{\circ} 04^{\prime} 38.2^{\prime \prime} \mathrm{N} 90^{\circ} 15^{\prime} 58.4$ 'W, $\mathrm{N}=9$. LSUMZ 14508, Guatemala, río Asuchillo close to El Brito, río Maria Linda, Pacifico, $\mathrm{N}=12$. LSUMZ 14507, Guatemala, quebrada El Arco, río Cahabon, N = 7. Poeciliopsis presidionis: AMNH 28616, Mexico, Nayarit, estero de San Blas, $N=20$. CAS 54410, Mexico, Sinaloa, Culacan, río Elota, 58 mi. S of Culacan, $\mathrm{N}=49$. Poeciliopsis prolifica: $\mathrm{SU} 18552$, Mexico, Sinaloa, Sinaloa near Los Mochis, $\mathrm{N}=61$. Poeciliopsis turrubarensis: AMNH 31545, Guatemala, Jutiapa-Santa Rosa, río Los Esclavos at Los Cerritos, $\mathrm{N}=10 . \mathrm{LSUMZ} 14509$, Guatemala, río Asuchillo near El Brito, río Maria Linda, $\mathrm{N}=2$. TU 24130, Costa Rica, Puntarenas, $3 \mathrm{~km}$ W of Esparta, Panamaerican Hwy, río Barranca, $\mathrm{N}=62$. Poeciliopsis viriosa: CAS 54387, Mexico, Sinaloa, arroyo Zapotillo E of Concordia on road from Mazatlan to Durango, $\mathrm{N}=21$. Priapella intermedia: AMNH 78021, Mexico, Oaxaca, creek near rancho San Carlos, at junction of ríos Sarbia and Coatzacoalcos, N = 4. Priapichthys annectens: TU 25193, Costa Rica, Cartago, río Azul near Turrialba, río Azul, río Parismina, N = 89. Quintana atrizona: MCZ 34192, Cuba, Great Antilles, isla de Pinos, arroyo Bibijagua, N = 4. Scolichthys greenwayi: USAC 1785, Guatemala, Alta Verapaz, río Dolores, $\mathrm{N}=20$. USAC 1788, Guatemala, Alta Verapaz, San Pedro Carcha, río Sesajal, $N=10$. LSUMZ 14506, Guatemala, quebrada El Arco, río Cahabon, $\mathrm{N}=1$. LSUMZ 14505 Guatemala, río Chibut, río Candelaria YalicarBecken, río Icvolay, río Chixoy, río Salinas, $\mathrm{N}=23$. Tomeurus gracilis: MCP 43195, Brazil, Amapa, río Muruamum, $00^{\circ} 14^{\prime} 02^{\prime} \mathrm{N}$ $51^{\circ} 19^{\prime} 45^{\prime} \mathrm{W}, \mathrm{N}=3$. Xiphophorus alvarezi: USAC 1782, Guatemala, Alta Verapaz, Lanquin, trib. río Dolores, $1 \mathrm{~km}$ of Santa Barbara village, Las Bovedas, $\mathrm{N}=4$. LSUMZ 14505, Guatemala, río Chibut, río Candelaria Yalicar-Becken, río Icvolay, río Chixoy, río Salinas, $\mathrm{N}$ =3. Xiphophorus mayae: LSUMZ 14336, Guatemala, río Trincheras, Campo Dos Village, 214 m, 15²3'45.2”N 8902'41.3”W, N = 2.
Appendix 2. Descriptions of characters and alternative states. Characters are grouped by functional group as follows: jaws, dentary, neurocranium, suspensorium, branchial arches, pectoral fin and girdle, dorsal fin, vertebrae and ribs, caudal skeleton, anal fin and gonopodium, scales and pigmentation, external morphology, and cephalic sensory system.

\section{Oral Jaws}

1. Shape of the tip of the distal arm of maxilla (Fig. 4): (0) square, (1) round, (2) triangular.

The distal arm of the maxilla present different shape at the tip, the character was considered square if it had a completely flat bottom, even if the tip was slender. If the shape of the tip was slightly or totally rounded, it was given character state 1 . When the tip ended in a peak, even if it had round edges it was given character state 2 .

2. Notch on the dorsal portion of maxilla (Costa, 1998, ch. 3): (0) present, (1) absent.

A dorsal notch was present in most of the species analyzed and was shared by most of the Poeciliinae and Profundulidae.

\section{Width of the distal arm of maxilla (Costa 1998, ch. 6; Fig.} 4): (0) slender, (1) broad.

\section{Length of the dorsal process of the maxilla compared with} ventral process of the maxilla (Fig. 4): (0) long, (1) same length, (2) short.

This character was a modification of character 7 in Costa (1998), who proposed that the shape of the dorsal process of the maxilla was continuous or curved. In this study, the size of the dorsal process was compared with the size of the ventral process.

5. Length of premaxillary ascending process (Fig. 4): (0) dorsal margin with a simple, undivided ascending process, (1) ascending process divided, posterior ramus longer, but less than twice length than anterior ramus, (2) ascending process divided, posterior and anterior rami of subequal length, (3) ascending process divided, posterior ramus more than twice length of anterior ramus.

Lucinda \& Reis (2005) used six character states to describe the shape of the ascending process of the premaxilla, including aspects of both shape and size; in this study each of these aspects of trait diversity is coded as a separate character (characters 4 and 5).

\section{Shape of premaxillary ascending process (Parenti, 1981;} Costa, 1998, ch. 18; Lucinda \& Reis, 2005, ch. 12, figs. 5af; Fig. 4): (0) triangular, (1) rounded, (2) triangular with rounded tip.

Lucinda \& Reis (2005) used six character states to describe the shape of the ascending process of the premaxilla, including aspects of both, shape and size; in this study each of these aspects of trait diversity, is coded as a separate character (characters 4 and 5). 


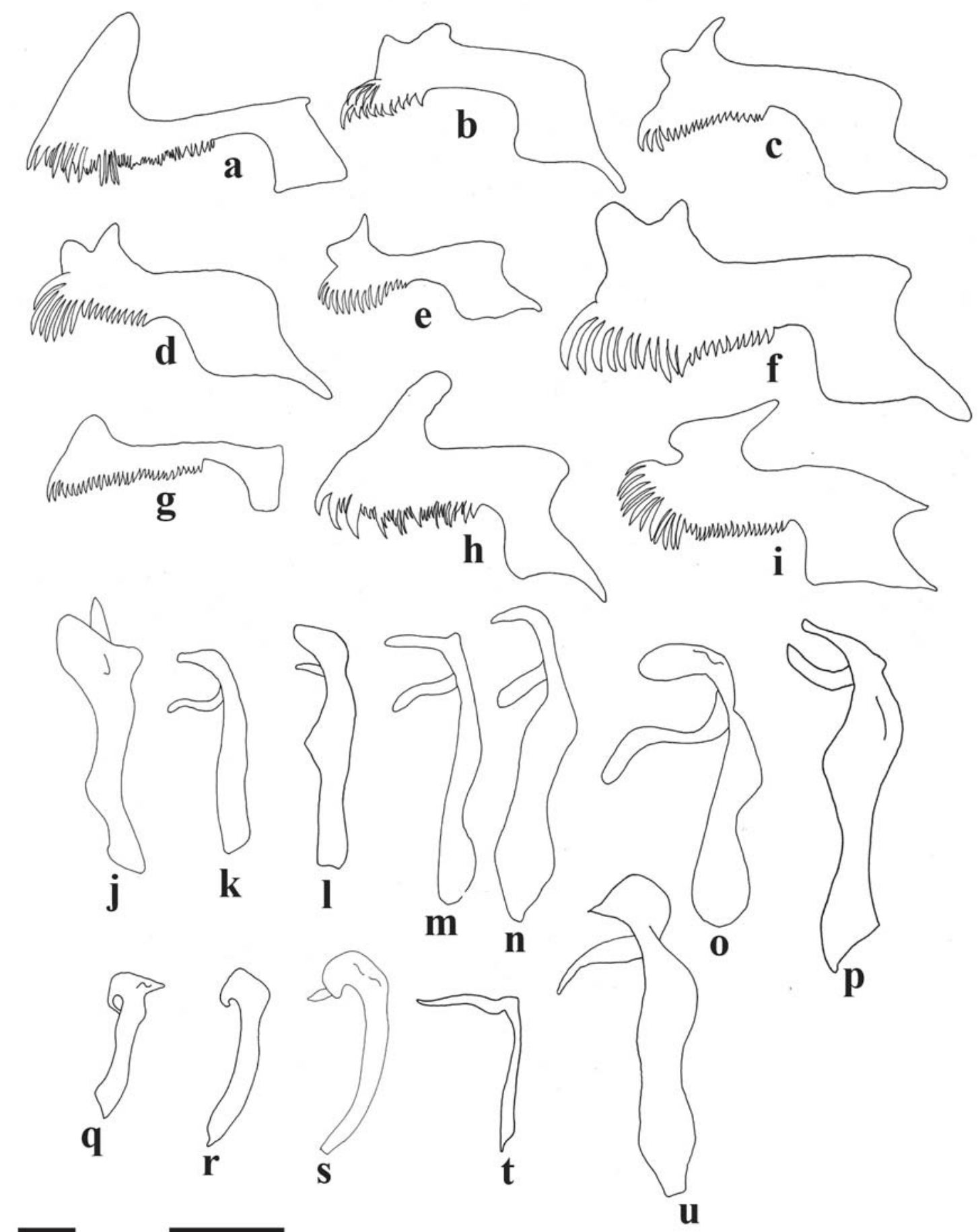

g, h, s a-f, i-r, t-u

Fig. 4. Lateral view of premaxilla in: a) Pseudoxiphophorus diremptus, LSUMZ 14337; b) Xiphophorus mayae, LSUMZ 14336; c) Carlhubbsia stuarti, USAC 204; d) Phallichthys amates, CAS 587873; e) Phallichthys fairweatheri, USAC 1797; f) Xiphophorus alvarezi, USAC 1782; g) Alfaro hubber, USAC 850; h) Profundulus labialis, LSUMZ 14328 ; i) P. guatemalensis, USAC 769; maxilla in: j) Pseudoxiphophorus diremptus, LSUMZ 14337; k) Poeciliopsis latidens, CAS 54436; l) Brachyrhaphis olomina, TU 24997; m) Xenophallus umbratilis, TU 186285; n) Poecilia rositae, USAC 1822; o) Poeciliopsis gracilis, TU 84966; p) Alfaro cultratus, TU 24927; q) Pamphorichthys araguaiensis, MCP 40919; r) Heterandria formosa, TU 24002; s) Limia melanogaster, MCZ 258314; t) Fluviphylax pygmaeus, MCP 38830; u) Profundulus guatemalensis, USAC 769. Scale bars $=1 \mathrm{~mm}$. 
7. Anterior border of the ventral arm of the maxilla (Lucinda \& Reis, 2005, ch. 14, fig. 6; Fig. 4): (0) concave, (1) straight, (2) convex.

Lucida \& Reis (2005) proposed the conditions in states 0 and 1 , and here we added the condition of state 2 as observed in several species not examined by Lucinda \& Reis (2005).

8. Posterior border of the ventral arm of the maxilla (Figs. 4): (0) concave, (1) straight, (2) convex.

9. Medial surface of ascending process of the premaxilla (Ghedotti, 2000, fig. 3; Lucinda \& Reis, 2005, ch. 11): (0) angled forming a gap between proximal ends, (1) slightly angled, (2) straight.

Ghedotti (2000) proposed the states approximately straight and angled laterally at the proximal end. Lucinda \& Reis (2005) recognized the state straight in Scolichthys, Neoheterandria, Pseudopoecilia, Cnesterodon, and Phallotorhynus. They found a slightly angled state in Alfaro, Brachyrhaphis, Priapichthys, Priapella, and H. formosa.

10. Posteroventral process of dentary (Costa, 1998, ch. 20, fig. 3b): (0) present, (1) reduced.

This character was present only in the genus Profundulus. The other species had a reduced process of the dentary.

11. Shape of dentary near symphysis (Costa, 1998, ch. 19, fig. 3; Ghedotti, 2000, ch. 19, fig. 5): (0) slender, (1) deep.

12. Notch on dentary (Rosen \& Bailey, 1963, figs. 21c, f; Ghedotti, 2000, ch. 21, figs. 5a-e; Lucinda \& Reis, 2005, ch. 16): (0) present, (1) absent.

13. Medially directed lamella on posteroventral dentary and anteromedially directed lamella on ventral anguloarticular (Rauchenberger, 1989; Costa, 1998, ch. 20; Ghedotti, 2000, fig. 5, ch. 21; Fig. 5): (0) present, (1) absent.

14. Retroarticular (Rauchenberger, 1989, fig. 5; Costa, 1998, ch. 21; Ghedotti, 2000, ch. 24, fig. 5; Fig. 5): (0) diminutive (do not reach aperture), (1) small (reaching the aperture origin), (2) long (reaching the aperture origin).

15. Shape of ventral process of the anguloarticular (Costa, 1998; Ghedotti, 2000, ch. 23, fig. 5; Lucinda \& Reis, 2005, ch. 18; Fig. 5): (0) reduced (almost not distinguishable) or absent, (1) short (smaller than the first process length), (2) long (longer than the first process length).

16. Pronounced indentation on the anterior base of coronoid process of anguloarticular (Costa, 1998, ch. 24; Lucinda \& Reis, 2005, ch. 19; Fig. 5): (0) absent, (1) present.

\section{Neurocranium}

17. Anterior margin of frontals (Ghedotti, 1998, 2000, ch. 2; Lucinda \& Reis, 2005, ch. 1): (0) straight (Ghedotti, 1998, figs. 2b-d), (1) extending anteriorly between the nasals (Ghedotti, 1998, fig. 2a).

Ghedotti (1998) reported extended frontals for Alfaro cultratus. Lucinda \& Reis (2005) reported that the frontal extends anteriorly between the nasals for Fluviphylax, Alfaro, Priapichthys, Priapella (not included here), and Belonesox.

18. Parietals (Rosen, 1967; Parenti, 1981; Rauchenberger, 1989, fig. 1; Ghedotti, 2000, fig. 3; Lucinda \& Reis, 2005, ch. 2): (0) long, (1) medium, (2) narrow or short, (3) absent.

Lucinda \& Reis (2005) proposed three character states, reporting large parietals for Jenynsia, Alfaro, Brachyrhaphis, Priapichthys, H. formosa, Gambusia, Belonesox, Neoheterandria, Scolichthys, Girardinus (not included in the study), and Xiphophorus. Ghedotti (2000) reported reduced parietals for Tomeurus, Phalloceros, Poecilia, Girardinus, and Phallichthys, and the absence of parietals in Cnesterodon, Poeciliopsis, and Phallotorynus. Lucinda \& Reis (2005) reported this absence condition for Pseudopoecilia, Phalloptychus, Xenodexia, Pamphorhichthys, Micropoecilia, and Phallotorynus. Parenti (1981) reported absence of parietals as synapomorphic among cyprinodontines and other species such as Fluviphylax.

19. Epiotic processes in adults (Rosen, 1967; Rauchenberger, 1989; Ghedotti, 1998, ch. 5; Ghedotti, 2000, ch. 4, fig. 3; Lucinda \& Reis, 2005, ch. 3): (0) large (beyond first vertebra; Ghedotti, 1998, figs. 2a-b, d), (1) medium (reaches first vertebra), (2) small (does not reach first vertebra; Ghedotti, 1998, fig. 2c), (3) absent (Ghedotti, 1998).

Ghedotti recognized three states for this character, in the present study was included another state, a medium size state, when the epiotic processes reach the first vertebra but do not go beyond it (referred to as "long" by Lucinda \& Reis, 2005). According to Ghedotti (1998), this character was not a synapomorphy for Anablepidae because some species of that family lack epiotic processes. Ghedotti (1998) stated that the epiotic processes in Fluviphylax obscurum were absent, while in this study the specimen of $F$. pygmaeus examined possessed small epiotic processes (state 2). Lucinda \& Reis (2005) stated that long epiotic processes were present in Jenynsia, Aplocheilichthys Phallichthys, Alfaro, Poeciliopsis, Quintana, and Carlhubbsia. According to Lucinda \& Reis (2005), Priapichthys, Girardinus, Poecilia, Neoheterandria, Scolichthys, Xiphophorus, and Limia have medium-sized epiotic processes, while short processes are present in Heterandria and Pseudopoecilia. Ghedotti (2000) reported the absence of epiotic processes in Tomeurus and Cnesterodon. Lucinda \& Reis (2005) also reported them absent in Pamphorichthys and Micropoecilia.

20. Supraoccipital process (Lucinda \& Reis, 2005, ch. 4): (0) bifid, outer portion large (Lucinda \& Reis, 2005; fig. 4c), (1) bifid, outer portion diminutive (Lucinda \& Reis, 2005; fig. 4b), (2) simple, not split (Lucinda \& Reis, 2005; fig. 4a), (3) absent. 

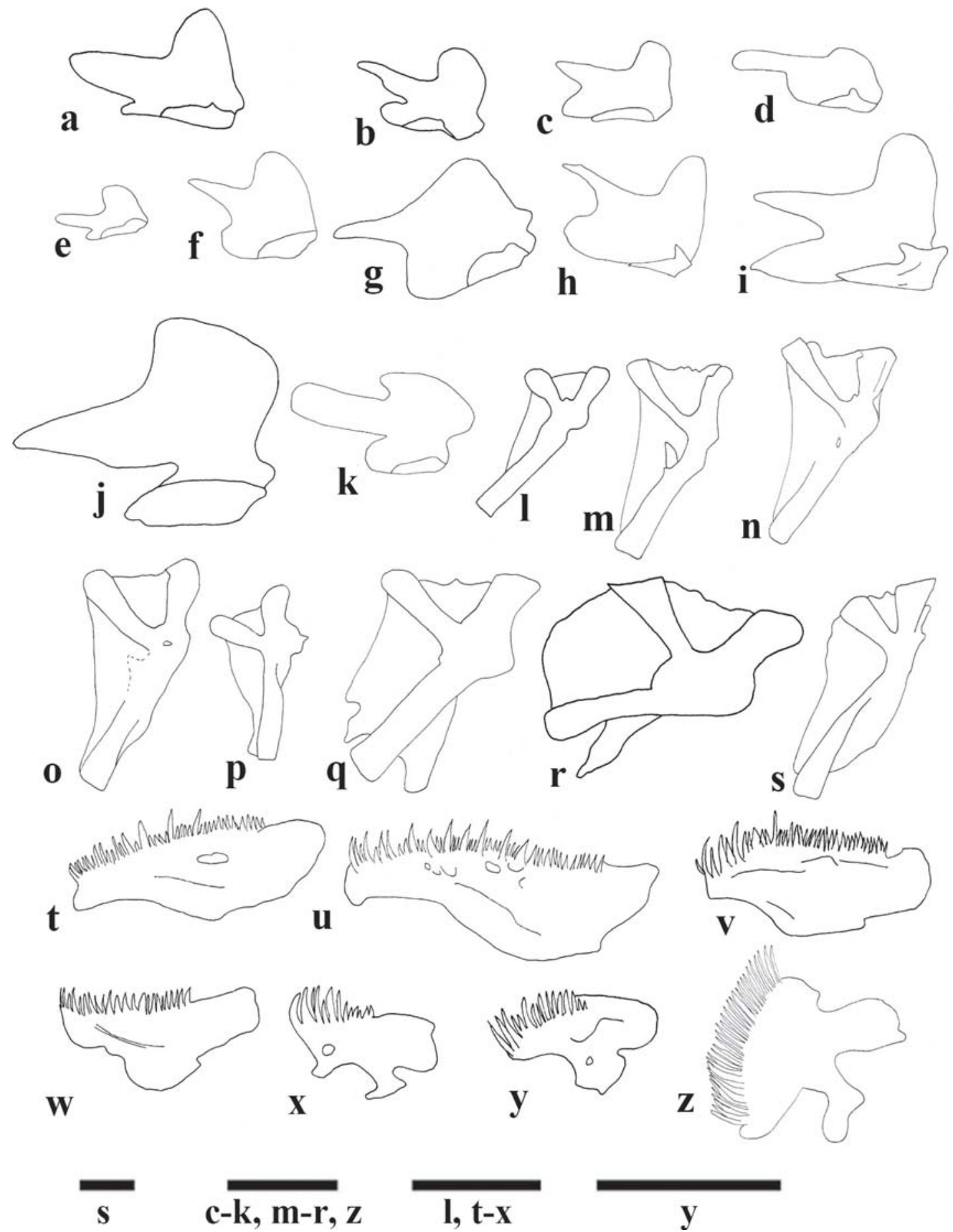

\section{$\mathbf{y}$}

Fig. 5. Lateral view of retroarticular in: a) Phalloceros buckupi, SU 64230; b) Heterandria formosa, TU 24002; c) Brachyrhaphis olomina, TU 24997; d) Xenophallus umbratilis, TU 186285; e) Phallichthys fairweatheri, USAC 797; f) Carlhubbsia stuarti, USAC 204; g) Poeciliopsis turrubarensis, TU 24130; h) Brachyrhaphis terrabensis, AMNH 2503; i) Pseudoxiphophorus bimaculatus, TU 183396; j) Jenynsia eirmostigma, MCP 40527; k) Phalloceros caudimaculatus, MCP 40527; hyomandibula in: 1) Heterandria formosa, TU 24002; m) Pseudoxiphophorus obliquus, LSUMZ 14339; n) Pseudoxiphophorus diremptus, LSUMZ 14337; o) Pseudoxiphophorus bimaculatus, TU 183396; p) Brachyrhaphis olomina, TU 24997; q) Jenynsia eirmostigma, MCP 40527; r) Anableps dowi, TU 39076; s) Profundulus guatemalensis, USAC 769; dentary in: t) Pseudoxiphophorus obliquus, LSUMZ 14339; u) Pseudoxiphophorus diremptus, LSUMZ 14337; v) Brachyrhaphis episcopi, SU 50303; w) Brachyrhaphis olomina, TU 24997; x) Pamphorichthys araguaiensis, MCP 40919; y) Heterandria formosa, TU 24002; z) Profundulus guatemalensis, USAC 769. Scale bars $=1 \mathrm{~mm}$. 
In this study, this character was modified from Lucinda \& Reis (2005) by adding state 3. Lucinda and Reis (2005) reported that Girardinus and Pamphorichthys have minute external bifid halves minute, while Phalloceros and Cnesterodon have a large external half.

21. Supraoccipital crest robust and long (Ghedotti, 1998): (0) absent, (1) present.

22. Ascending process of parasphenoid (Ghedotti, 1998, 2000, ch. 4, figs. 3b, f-g; Lucinda \& Reis, 2005, ch. 20): (0) long (Ghedotti, 1998, fig. 4), (1) short.

Ghedotti (1998) stated that for most species of Jenynsia and Fluviphylax examined the parasphenoid was short. Only two states were examined in this study because Xenodexia was not available for loan.

23. Vomer (Ghedotti, 2000, ch. 6, figs. 3f-h): (0) present, (1) absent.

Vomer was present (state 0 ) in most of the species.

Suspensorium

24. Extent and shape of dorsomedial lamella of the autopalatine (Costa, 1998, ch. 29, fig. 4): (0) long, (1) short, (2) absent.

25. Shape of cartilaginous head of autopalatine (Costa, 1998, ch. 31, fig. 4c): (0) narrow, (1) wide.

26. Extent of lateral lamella of the hyomandibula (Costa, 1998, ch. 35, fig. 4; Ghedotti, 1998, ch. 23, fig. 8; Ghedotti, 2000, ch. 29, figs. 6b-d; Fig. 5): (0) not expanded (1) expanded (Ghedotti, 1998, fig. 8c).

27. Shape of the medial process of the lachrymal (Ghedotti, 2000, ch. 25, fig. 4): (0) short and broad, (1) long and narrow.

28. Shape of the dorsoposterior region of lachrymal bordering the orbit (Ghedotti, 2000, ch. 26, figs. 4a-d): (0) dorsally indented, (1) without indentation, (2) short.

29. Dorsoposterior process of the autopalatine (Ghedotti, 2000, ch. 27, fig. 6): (0) long, (1) short, (2) absent.

30. Anterior margin of the dermopalatine (Ghedotti, 2000, ch. 27, fig. 6): (0) straight, (1) concave, (2) convex.

\section{Branchial skeleton}

31. Shape of dorsal process of urohyal (Costa, 1998, ch. 37, fig. 5): (0) straight, (1) bent.

32. Condyles on anterior portion of anterior ceratohyal (Costa, 1998, ch. 42; Parenti, 1981, fig. 28): (0) two, (1) one.

33. Anterior process of anterior ceratohyal extending ventrally, to ventral hypohyal (Ghedotti, 2000, fig. 8; Lucinda \& Reis, 2005, ch. 24): (0) present, (1) absent.
According to Lucinda \& Reis (2005), the absence of the anterior process was a synapomorphy for Poeciliinae except Tomeurus, Brachyrhaphis, and Heterandria.

34. (Lucinda \& Reis, 2005, ch. 23): First and second branchiostegal rays united at the base: (0) absent, (1) present.

According to Lucinda \& Reis (2005), Scolichthys and Neoheterandria present a synapomorphic condition that branchiostegal rays were united at the base.

35. Anterior margin of the first hypobranchial (Ghedotti, 2000, ch. 35, figs. 9a-b, Lucinda \& Reis, 2005, ch. 29): (0) straight, (1) concave.

36. Posterior border of first hypobranchial with a pronounced concavity (Costa, 1996): (0) absent, (1) present.

37. Teeth on the second and third hypobranchials (Ghedotti, 2000, ch. 36, fig. 9): (0) absent, (1) present.

38. Cartilaginous heads on the third hypobranchial (Ghedotti, 2000, ch. 37, fig. 9): (0) two heads, (1) one, continuous, (2) none.

39. Teeth on the fourth ceratobranchial (Ghedotti, 2000, ch. 38, fig. 9; Lucinda \& Reis, 2005, ch. 27): (0) absent, (1) present.

40. Teeth in the fifth ceratobranchial (Lucinda \& Reis, 2005, ch. 28): (0) wide regular, (1) narrow irregular, (2) absent.

41. Third and fourth pharyngobranchial toothplates (Ghedotti, 2000, ch. 41, fig. 10b; Lucinda \& Reis, 2005, ch. 26): (0) fused, (1) separated.

Pectoral fin and girdle

42. Number of pectoral-fin rays (Miller, 1979; Rosen, 1979; Parenti, 1981; Ghedotti, 1998, ch. 34): (0) 10 or less, (1) 11 12, (2) 13-14, (3) 15 or more.

43. Shape of supracleithrum (Costa, 1998, ch. 45, fig. 4a; Ghedotti, 2000, ch. 54, fig. 12; Fig. 6): (0) broad, (1) narrow, (2) absent.

44. Fusion of supracleithrum with post-temporal (Costa, 1998, ch. 76; Fig. 6): (0) absent, (1) present.

45. Position of pectoral-fin origin in relation to midline of the body (Ghedotti, 2000, ch. 51; Lucinda \& Reis, 2005, ch. 32): (0) above, (1) below.

46. Ventral arm of post-temporal (Ghedotti, 2000, ch. 52, figs.12a-c; Fig. 6): (0) ossified, (1) non-ossified.

47. Posterior extension of dorsal enclosure of cleithrum (Ghedotti, 2000, ch. 55, figs. 12a-d; Fig. 6): (0) slightly curved, (1) straight. 


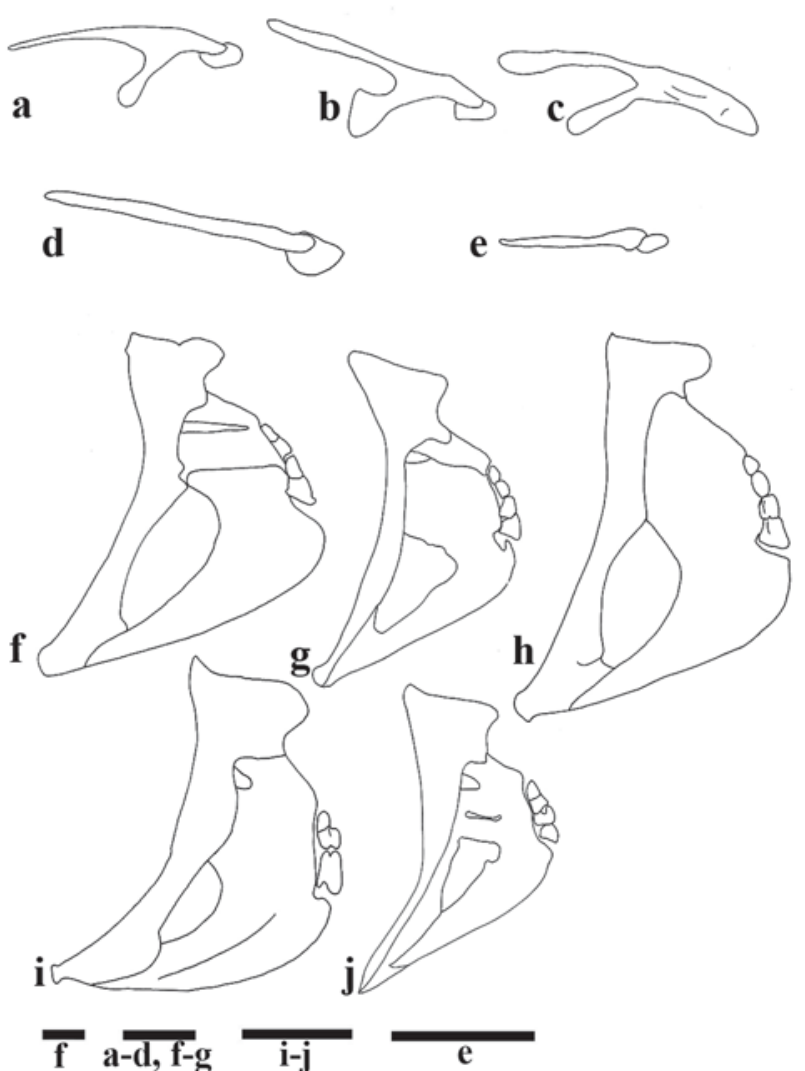

Fig. 6. Lateral view of post-temporal and supracleithrum in: a) Brachyrhaphis terrabensis, AMNH 2503; b) Alfaro cultratus, TU 24927; c) Anableps dowi, TU 39076; d) Pseudoxiphophorus bimaculatus, TU 183396; e) Heterandria formosa, TU 24002; pectoral fin girdle in: f) Pseudoxiphophorus bimaculatus, TU 183396; g) Brachyrhaphis terrabensis, AMNH 2503; h) Brachyrhaphis episcopi, SU 50303; i) Phalloceros caudimaculatus, MCP 40527; j) Heterandria formosa, TU 24002. Scale bars $=1 \mathrm{~mm}$.

48. Broad postcleithrum: (0) absent, (1) present (Costa, 1998).

49. Dorsal proximal pectoral radials (Ghedotti, 2000, ch. 56, fig. 12; Figs. 6, 17): (0) fused, (1) free.

50. Posteroventral coracoid (Ghedotti, 2000, ch. 57, fig. 16; Fig. 6): (0) straight, (1) round.

51. Post-temporal (Rosen, 1967, fig. 4; Lucinda \& Reis, 2005, ch. 31; Fig. 6): (0) bifid, (1) unbranched.

Pelvic fin and girdle

52. Number of pelvic-fin rays (Ghedotti, 2000, ch. 60; Lucinda \& Reis, 2005, ch. 33): (0) 3-4, (1) 6-8.

53. Ventral lamella on central part of basipterygium in males (Ghedotti, 2000, ch. 6, figs. 13a-e): (0) absent, (1) present.

54. Medial process of basipterygium in males (Ghedotti, 1998, ch. 39; Ghedotti, 2000, ch. 62): (0) separated (Ghedotti, 1998 fig. 14b), (1) overlap (Ghedotti, 1998, fig. 14a), (2) fused.

55. Position of pelvic girdle in adult males (Ghedotti, 2000, ch. 65; Lucinda \& Reis, 2005, ch. 35): (0) same as females, (1) more anterior in males, (2) more posterior in males.

The character states proposed by Lucinda \& Reis (2005) were reduced in this study.

56. Pelvic-fin insertion between the pleural ribs of vertebrae 3 to 6 (Costa, 1998, ch. 85): (0) absent, (1) present.

57. Pelvic-fin length in adult males (Lucinda \& Reis, 2005, ch. 34): (0) short (extending up to anal-fin origin), (1) medium (extending beyond origin of anal fin but do not reaching end of anal fin), (2) long (reaching beyond end of anal fin).

58. Ray 3 of the pelvic fin expanded distally and with several branches (Rodriguez, 1997): (0) absent, (1) present.

59. Ray 2 of the pelvic fin with a distal triangular shape, comb-like, formed by spiny bony processes of these segments of the ray and covered by a fleshy membrane (Rodriguez, 1997; Fig. 8): (0) absent, (1) present.

60. Second ray of pelvic fin separated from rays 3-5 by a large gap (Rodriguez, 1997): (0) absent, (1) present.

61. Dorsolateral process of the basipterygium in adult males (Lucinda \& Reis, 2005, ch. 36, fig. 8): (0) short, (1) long.

62. Lateral keel of the basipterygium in adult males (Lucinda \& Reis, 2005, ch. 38): (0) absent, (1) present.

Lucinda \& Reis (2005) reported that this was a derived feature in Scolichthys, Pamphorichthys, Poeciliopsis, and Phalloptychus.

63. Shape of anterior tip of the basipterygium in adult males (Lucinda \& Reis, 2005, ch. 37, figs. 8c-d, 9, 11): (0) triangular,

(1) triangular with round tip (2) sinuous, (3) pointed, (4) round,

(5) round with keel-tip.

The character states used in this study differ from Lucinda \& Reis (2005).

64. Narrowing of the lateral surface of the basipterygium in males (Lucinda \& Reis, 2005, ch. 39, fig. 9): (0) present, (1) absent.

\section{Axial skeleton}

65. Number of dorsal-fin rays in males (Rosen, 1979; Ghedotti, 2000, ch. 86; Lucinda \& Reis, 2005, ch. 64): (0) 9 or fewer, (1) 10-11, (2) 12 or more.

66. Position of dorsal-fin origin in adult males (Ghedotti, 1998, ch. 58; Ghedotti, 2000, ch. 87; Lucinda \& Reis, 2005: ch. 62): (0) anterior to vertebra $9,(1)$ between vertebrae 9 and 
$10,(2)$ between vertebrae $10-11$ or $11-12$, (3) between vertebrae 12-13, (4) between vertebrae 13-14, (5) behind vertebra 14.

This character was coded into more states than in Ghedotti (1998).

67. Number of vertebrae (Regan, 1913; Miller, 1979; Rosen, 1979; Parenti, 1981; Rauchenberger, 1989; Ghedotti, 1998, ch.31): (0) 25-26, (1) 27, (2) 28, (3) 29, (4) 30, (5) 31 or more.

Ghedotti (1998) coded this character for the family Anablepidae using only two character states, fewer than 45, and 45 or more. This character was coded into more states than in previous publications.

68. Total number of vertebrae with a widened neural spines: (0) none, (1) one, (2) two, (3) three, (4) four, (5) nine.

69. Distal tips of pleural ribs associated with sixth to tenth vertebrae (Rosen \& Bailey, 1963, figs. 17, 26, 49; Rodriguez, 1997, ch. 1; Ghedotti, 2000, ch. 50): (0) slender and straight, (1) slender and curved, (2) thickened and curved.

70. Haemal arches and spines of vertebrae 13-17 in males (Lucinda \& Reis, 2005, ch. 47): (0) rudimentary, not modified into gonapophyses, (1) modified into gonapophyses.

71. Size of caudal accessory cartilage between distal neural spines of preural vertebrae 3 and 4 (Costa, 1998; Ghedotti, 2000, figs. 17a-b; Fig. 7): (0) large, (1) small.

72. Shape of caudal accessory cartilage between distal neural spines of pleural vertebrae 3 and 4 (Fig. 7): (0) rounded, (1) ovoid, (2) squared, (3) n-shaped, (4) 7-shaped, or triangular.

73. Complete median horizontal gap between dorsal and ventral hypurals (Costa 1998): (0) absent, (1) present.

74. Hypural plate in adult males (Parenti, 1981; Ghedotti, 1998, ch. 59; Ghedotti, 2000, ch. 88, fig. 17; Lucinda \& Reis, 2005, ch. 131; Fig. 7): (0) posterior margin completely separate or bipartite, (1) with a median aperture of $3 / 4$ to $1 / 2$ of its size, (2) with a median aperture less than half its size, (3) fused.

75. Number of caudal-fin rays in contact with hypural plate (Lucinda \& Reis, 2005, ch. 132): (0) 7 or less, (1) 8-9, (2) 10 11, (3) $12-13$, , (4) $14-15$.

76. Ossification state of hypural plates: (0) fully ossified, (1) only tips of posterior margin cartilaginous, (2) 1/3 cartilage, (3) $2 / 3$ cartilage, (4) fully unossified.

\section{Anal fin and Gonopodium}

77. Male anal fin (Hubbs, 1924, Parenti, 1981, Ghedotti, 1998, ch. 41; Ghedotti, 2000, ch. 67, fig. 14; Lucinda \& Reis, 2005, ch. 86): (0) unmodified, almost identical to female anal fin, (1) modified into an intromittent organ, fleshy tube supported by more than three anal-fin rays, (2) modified into a gonopodium supported by anal-fin rays three to five.

78. Sexual laterality in males (Ghedotti, 1998, ch. 68; Ghedotti, 2000, ch. 94): (0) absent, (1) present (Ghedotti, 1998, fig. 24).

This character refers to laterally directed papillae in relation to the midline.

79. Male anal-fin length (gonopodium length) (Ghedotti, 2000, ch. 68): (0) short, extending from vertebrae 9 to vertebrae 15 , (1) medium, extending from vertebrae 16 to vertebrae 29, (2) long, extending further back from vertebrae 30 .

This character was coded taking into account the number of vertebrae from the position of the gonopodium origin to the last vertebrae reached by the gonopodial tip.

80. Number of anal-fin rays in females (Ghedotti, 1998, ch. 40; Ghedotti, 2000, ch. 69; Lucinda \& Reis, 2005, ch. 85): (0) 9 or less, (1) 10, (2) 11, (3) 12 or more.
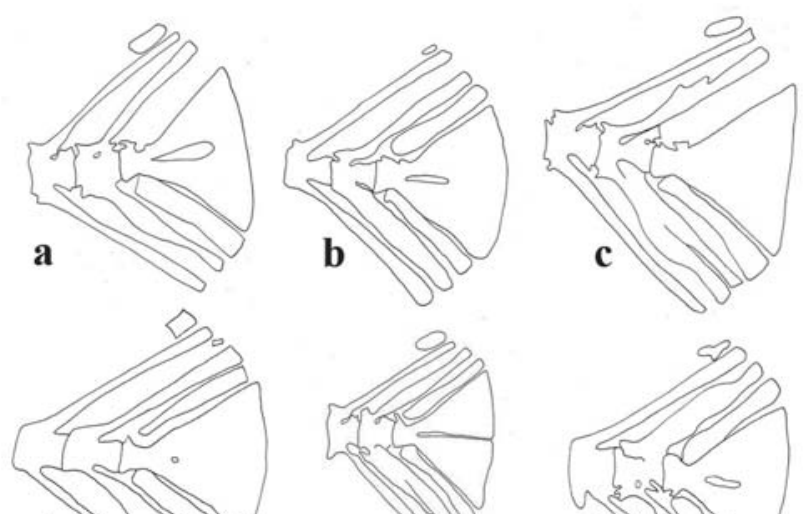

d
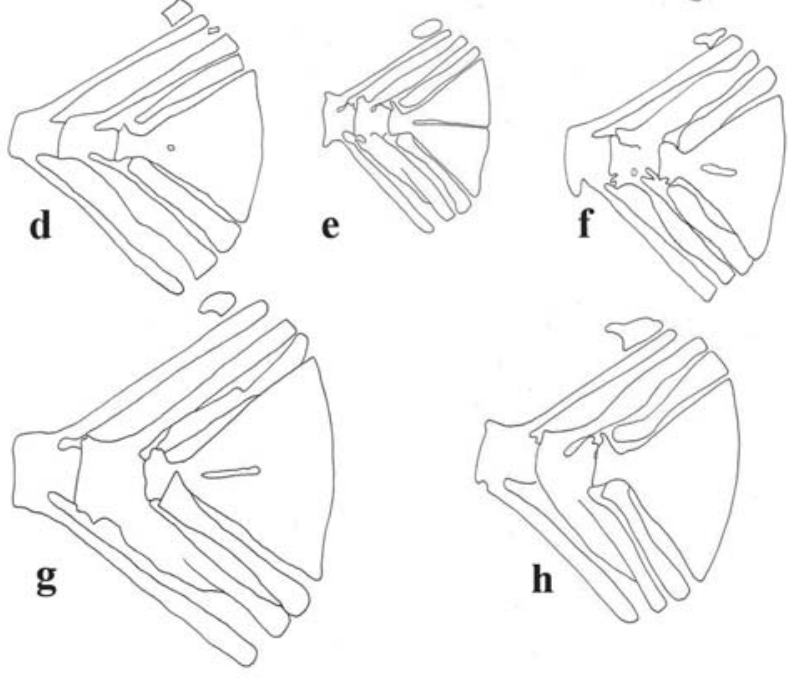

$\overline{\mathrm{e}, \mathrm{f}, \mathrm{g}} \overline{\mathrm{h}} \overline{\mathrm{a}, \mathrm{b}, \mathrm{c}, \mathrm{d}}$

Fig. 7. Lateral view of caudal-fin skeleton in: a) Phalloceros caudimaculatus, MCP 4052; b) Heterandria formosa, TU 24002; c) Gambusia affinis, TU 114758; d) Pamphorichthys araguaiensis, MCP 40919; e) Brachyrhaphis episcopi, SU 50303; f) Pseudoxiphophorus obliquus, LSUMZ 14339; g) Pseudoxiphophorus bimaculatus, CAS 78795; h) Brachyrhaphis rhabdophora, TU 84483. Scale bars $=1 \mathrm{~mm}$. 
81. Ventral margin of the gonopodium (Rosen, 1979): (0) straight, (1) concave behind spines.

82. Gonopodium symmetry (Rosen \& Bailey, 1959; Rosen 1979; Lucinda \& Reis, 2005, ch. 87): (0) symmetric, (1) asymmetric.

83. Distal tip of anal-fin ray 3 in males (Rosen \& Bailey, 1963, fig. 31; Ghedotti, 2000, ch. 72, fig. 14): (0) absent, (1) simple, (2) segmented, (3) with spinous cirri.

84. Fleshy palp on ventral surface of anal-fin ray 3 in males (Rosen \& Bailey, 1963, fig. 25; Rodriguez, 1997, fig. 5; Ghedotti, 2000, ch. 73; Lucinda \& Reis, 2005, ch. 88; Fig. 8): (0) absent, (1) present.

85. Pedicle at tip of anal-fin ray 3 (Rosen \& Bailey, 1963, fig. 31; Lucinda \& Reis, 2005, ch. 90; Figs. 8): (0) absent, (1) present.

86. Subdistal spines of anal-ray 3 curved forward (Rodriguez, 1997, Fig. 8): (0) absent, (1) present.

87. Anal-fin ray 3 with a large decurved hook distally and an ossified bladelike structure on the dorsal margin of he decurved hood (Rosen, 1979; Rodriguez, 1997; Fig. 8): (0) absent, (1) present.

88. Shape of anal-fin ray 4a (Rosen, 1979): (0) curved up, (1) curved down, (2) straight, (3) curved left, (4) curved right.

89. Keel structure situated ventrally on anal-fin ray 4 a (Rauchenberger, 1989; Fig. 8): (0) absent, (1) present.

90. Serrae on posterior margin of posterior branch of analfin ray 4 in adult males (Howell \& Hubbs, 1936; Miller, 1974; Ghedotti, 2000, ch. 74, fig. 15): (0) absent, (1) present.

91. Anal-fin ray $4 p$ with two series of distal serrae separated at the level of the hook of ray $5 \mathrm{a}$ in undifferentiated segments (Rosen, 1979; Rodriguez, 1997): (0) absent, (1) present.

92. Ventral projection of anal-fin ray 4 (Rauchenberger, 1989, figs. 20, 38; Lucinda \& Reis, 2005, ch. 113): (0) ventral projection absent, (1) ventral projection curved toward ray $3,(2)$ ray 3 curved toward ray 4 , (3) ventral projection twisted.

93. Depth of distal segments of anal-fin ray $4 p$ serrae (Rodriguez, 1997, ch. 12, fig. 5; Lucinda \& Reis, 2005, ch. 115): (0) segments absent, (1) wider than tall, (2) taller than wide.

94. Number of subdistal recurved spines on anal-fin ray $4 p$ (Lucinda \& Reis, 2005, ch. 116): (0) less than 9, (1) 10-12, (2) 13-14, (3) more than 15.
95. Elongate dorsal protuberance just behind recurved spines series of anal-fin ray $4 p$ (Rosen, 1979, fig. 6; Lucinda \& Reis, 2005, ch. 118): (0) absent, (1) present.

Elongate dorsal protuberance behind recurved spines of ray $4 \mathrm{p}$ (state 0 ) are absent in most species. An elongate dorsal protuberance behind recurved spines of ray $4 p$ (state 1) is present in Alfaro cultratus and Micropoecilia most Poecilia (except P. butleri), H. formosa, Brachyrhaphis terrabensis, Phallichthys, Limia, Xiphophorus, Scolichthys, Cnesterodon, Phalloceros, Priapichthys, and Pseudoxiphophorus (except a reversal in P. obliquus $P$. anzuetoi and P. diremptus).

96. Pedicle of anal-fin ray 3 united to anal-fin ray 4 (Rosen \& Bailey, 1963, fig. 31; Lucinda \& Reis, 2005, ch. 90; Fig. 8): (0) absent, (1) present.

97. Subdistal spines on gonopodial ray three enlarged ventrally to form a slight elbow along the ventral profile of the ray (Rosen, 1979): (0) absent, (1) present.

98. Distal fourth of gonopodium with an increased ventral flexure of its ray and moderately to strongly concave along ventral profile behind enlarged spines of ray 3 (Rosen, 1979): (0) absent, (1) present.

99. Terminal segment of gonopodial ray 4 a forming large decurved hook six times or more as long as the height from the base to the tip (Rosen, 1979): (0) absent, (1) present.

100. Large decurved terminal hook on gonopodial ray $4 a \mathrm{~L}-$ shaped or in form of open K (Rosen, 1979): (0) absent, (1) present.

101. Gonopodial ray $4 p$ as long as or longer than ray $5 a$ excluding the latter from direct contact with ray $4 a$ (Rosen, 1979): (0) absent, (1) present.

102. Penultimate short segments of gonopodial ray 4 a withdrawn from base of terminal membranous envelope and two or more in number (Rosen, 1979): (0) absent, (1) present.

103. Subdistal short segments of gonopodial ray 4a more than four in number and bearing ventral peg-like processes (Rosen, 1979): (0) absent, (1) present.

104. Intermediate segments of gonopodial ray $5 p$ enlarged, forming a semi-elliptic swelling (Lucinda \& Reis, 2005, ch. 112): (0) absent, (1) present.

105. Terminus of anal-fin rays $5 a, 5 p, 4 a, 4 p$ (Rauchenberger, 1989, fig. 23; Lucinda \& Reis, 2005, ch. 112): (0) directed dorsally, (1) straight, (2) directed ventrally, (3) Anal-fin ray 5 directed dorsally and ray 4 directed ventrally, (4) Ray 5 directed ventrally and ray 4 directed dorsally, (5) twisted. 

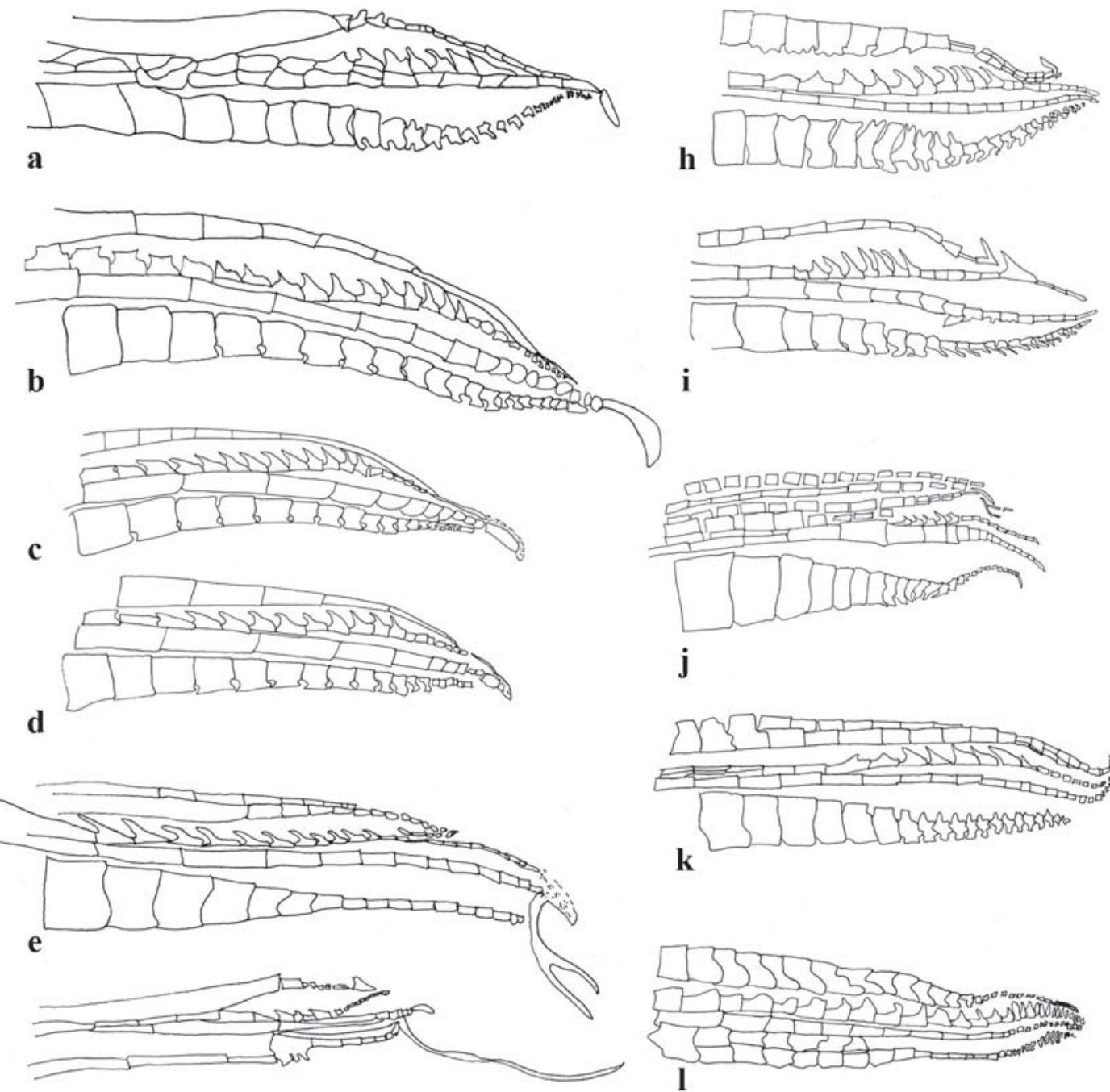

f
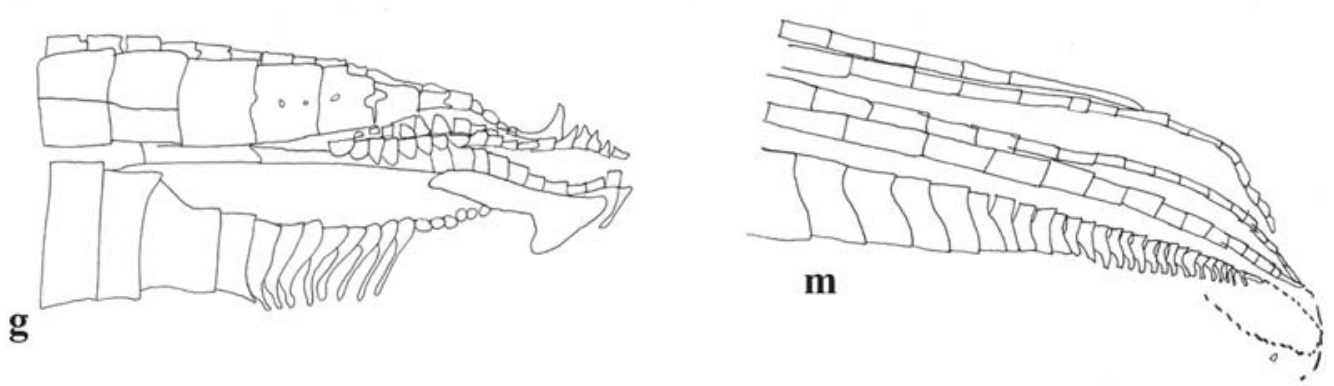

a

b-e, f-j

k-m

Fig. 8. Lateral view of the tip of gonopodium in: a) Heterandria formosa, TU 24002; b) Pseudoxiphophorus cataractae, LSUMZ 14338; c) Pseudoxiphophorus obliquus, LSUMZ 14339; d) Pseudoxiphophorus litoperas, USAC 1813; e) Phalloceros caudimaculatus, MCP 40527; f) Cnesterodon decemmaculatus, MCP 35215; g) Xiphophorus mayae, LSUMZ 14336; h) Poecilia rositae, USAC 1822; i) Gambusia affinis, TU 114758; j) Phallichthys fairweatheri, USAC 1797; k) Brachyrhaphis rhabdophora, TU 84483; I) Pamphorichthys araguaiensis, MCP 40919; m) Alfaro cultratus, TU 24927. Scale bars $=1 \mathrm{~mm}$. 
106. Posteriorly directed claw on distal tip of anterior branch of anal-fin ray 5 (Ghedotti, 2000, ch. 76, fig. 15; Fig. 8): (0) absent, (1) present.

107. Keel on posterior ventral surface of anal-fin ray 5 (Rodriguez, 1997, fig. 5f; Lucinda \& Reis 2005, ch. 119): (0) keel without axial projection, (1) keel projects anteriorly toward anal-fin ray $4 \mathrm{p}$.

108. Anal-fin ray 5 decurved away from body axis, around end of ray 4 (Rodriguez, 1997, fig. 5f; Lucinda \& Reis, 2005, ch.120): (0) absent, (1) present.

109. Groove on dorsal margin of anal-fin ray 5 (Rodriguez 1997, ch. 2; Lucinda \& Reis, 2005, ch. 121): (0) narrow, (1) broad.

110. Distal segment at tip of anal-fin ray 5a (Miller, 1974; Rauchenberger, 1989; fig. 20; Rosa \& Costa, 1993; Ghedotti, 2000, fig. 15a; Lucinda \& Reis, 2005, ch. 122; Fig. 8): (0) absent, (1) normal, (2) hooked, (3) triangular with spine, (4) with claw.

111. Dorsal expansion of anal-fin ray 5p (Rosa \& Costa, 1993; Lucinda \& Reis, 2005, ch. 124, fig. 28): (0) absent, (1) present.

112. Serrae on anal-fin ray $5 p$ (Lucinda \& Reis, 2005, ch. 125): (0) absent, (1) present.

113. Fusion between lower and upper branches of anal-fin ray 6a and 6p (Lucinda \& Reis, 2005, ch. 126): (0) absent, (1) partial, (2) total.

114. Degree of fusion among more distal elements of branches of anal-fin ray 6 (Lucinda \& Reis, 2005, ch. 127): (0) not fused, (1) partial, (2) total fused.

115. Distal portion of anal-fin ray 6 (Lucinda \& Reis, 2005, ch. 128): (0) not expanded, (1) expanded.

116. Inclination of gonactinost complex (anal-fin radials 3-5 in males) relative to longitudinal axis of body (Ghedotti, 2000, ch. 79, figs. 14, 16; Lucinda \& Reis, 2005, ch. 68): (0) absent, (1) backward, (2) forward, (3) perpendicular.

117. Small lateral process on base of fifth middle anal-fin radial (Rodriguez, 1997; Fig. 8): (0) absent, (1) present.

118. Gonactinost 1-5 (Rauchenberger, 1989, fig. 22; Fig. 9): (0) gonactinost 5 not ossified, (1) gonactinost 5 ossified and fused with gonactinosts 1-4 into a single laminar plate resembling spokes in a fan (2) gonactinost 5 ossified and not fused with gonactinosts 1-4, (3) gonactinosts 1-5 all ossified separately.

119. Gonactinost 8 (Rosen \& Bailey, 1963, fig. 53; Lucinda \& Reis, 2005, ch. 83; Fig. 9): (0) absent, (1) straight, (2) wing like.
120. Gonactinost 9 (Rosen \& Bailey, 1963, fig. 53; Lucinda \& Reis, 2005, ch.84; Fig. 9): (0) absent, (1) wing-like, (2) straight and smaller than other gonactinost, (3) straight and same size as other gonactinosts, (4) straight and half the size of other gonactinosts.

121. Distal portion of gonactinosts $3-\mathbf{4}$ completely fused: (0) absent, (1) present.

122. Ligastyle, a free haemal spine in adult males located dorsal to the gonopodial suspensorium and close to the vertebral column near the thirteenth vertebra (Ghedotti, 2000, ch. 44; Fig. 9): (0) cartilaginous, (1) ossified.

123. Ligastyle shape (Lucinda \& Reis, 2005, ch. 46, fig. 13): (0) short, (1) long one-axis, (2) long triangular.

124. Number of well-developed gonapophyses (Rodriguez, 1997, ch. 9, fig. 4; Lucinda \& Reis, 2005, ch. 48; Fig. 10): (0) rudimentary, (1) 1-2, (2) 3-4.

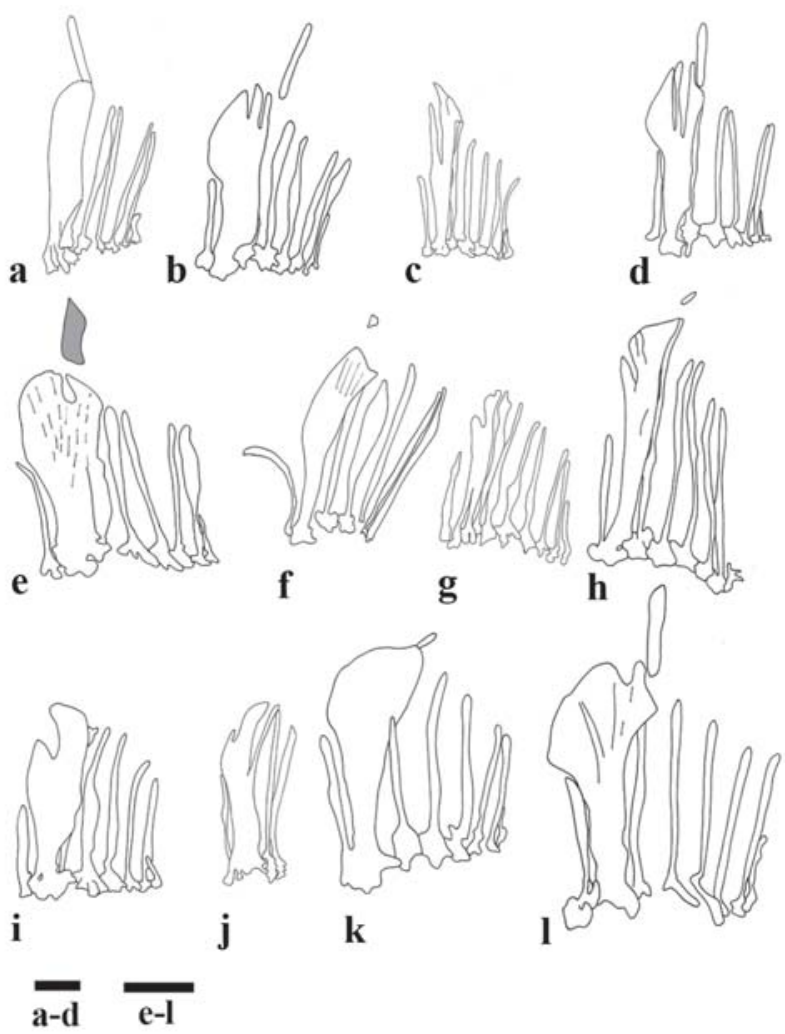

Fig. 9. Lateral view of gonopodial suspensorium in: a) Alfaro cultratus, TU 24927; b) Pseudoxiphophorus litoperas, USAC 1813; c) Brachyrhaphis terrabensis, AMNH 2503; d) Pseudoxiphophorus bimaculatus, CAS 78795; e) Pseudoxiphophorus obliquus, LSUMZ 14339; f) Heterandria formosa, TU 24002; g) Brachyrhaphis olomina, TU 24997; h) Gambusia affinis, TU 114758; i) Brachyrhaphis rhabdophora, TU 84483; j) Pamphorichthys araguaiensis, MCP 40919; k) Phallichthys fairweatheri, USAC 1797; l) Brachyrhaphis episcopi, SU 50303. Scale bars $=1 \mathrm{~mm}$. 

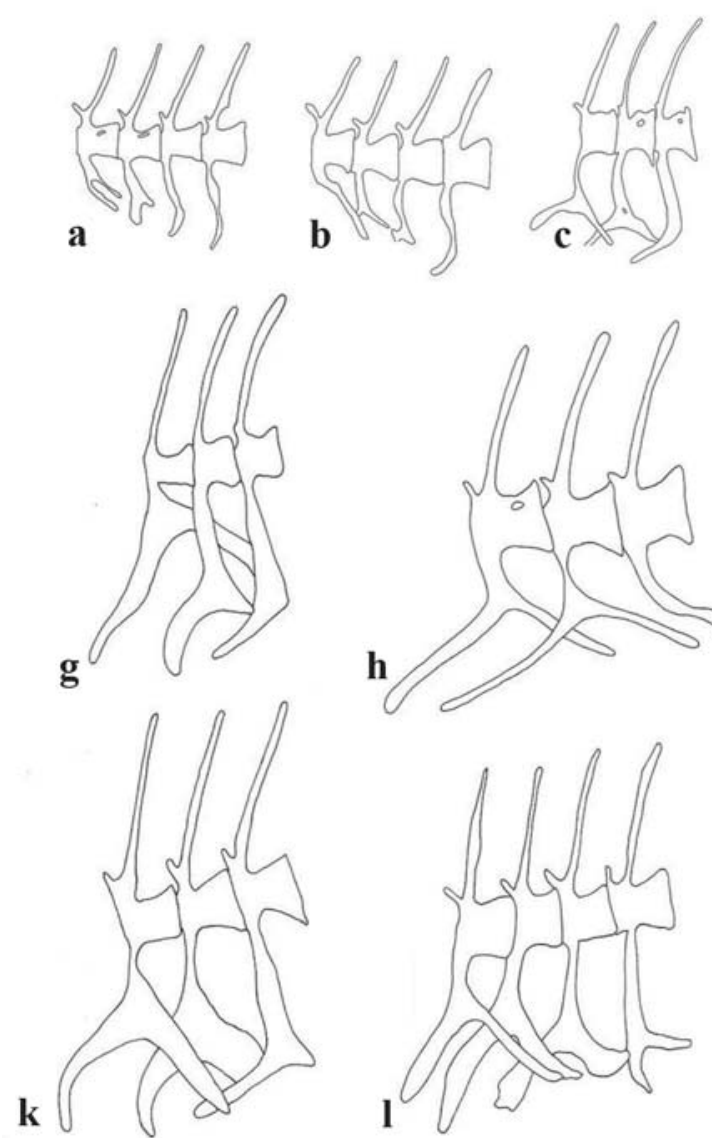

h

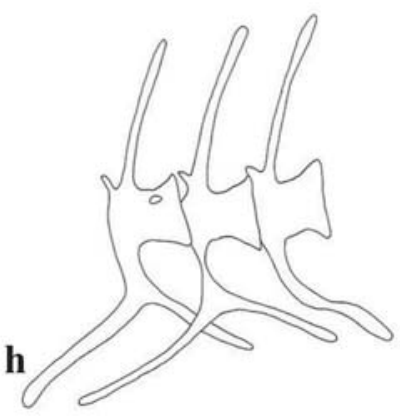

d
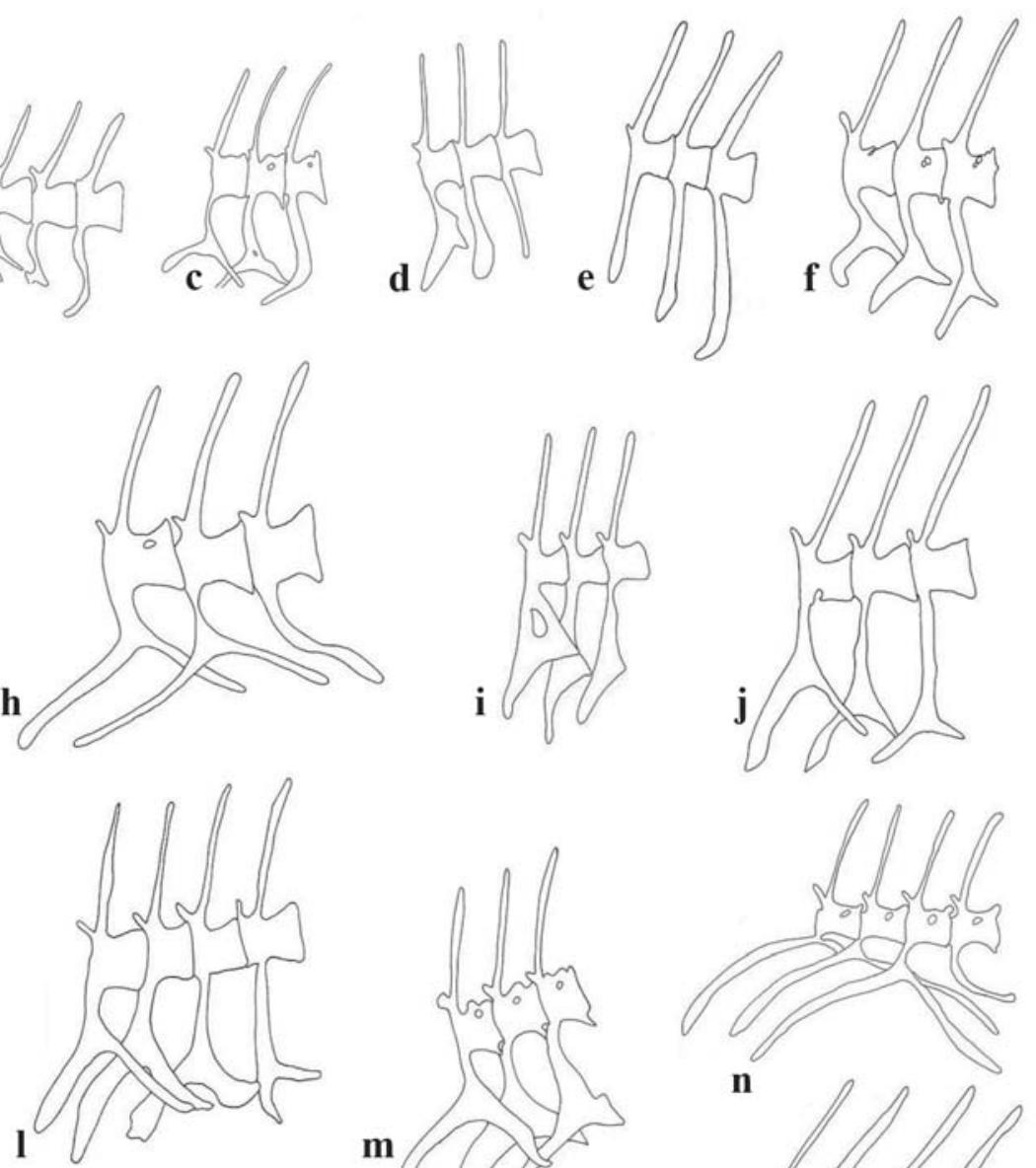

m
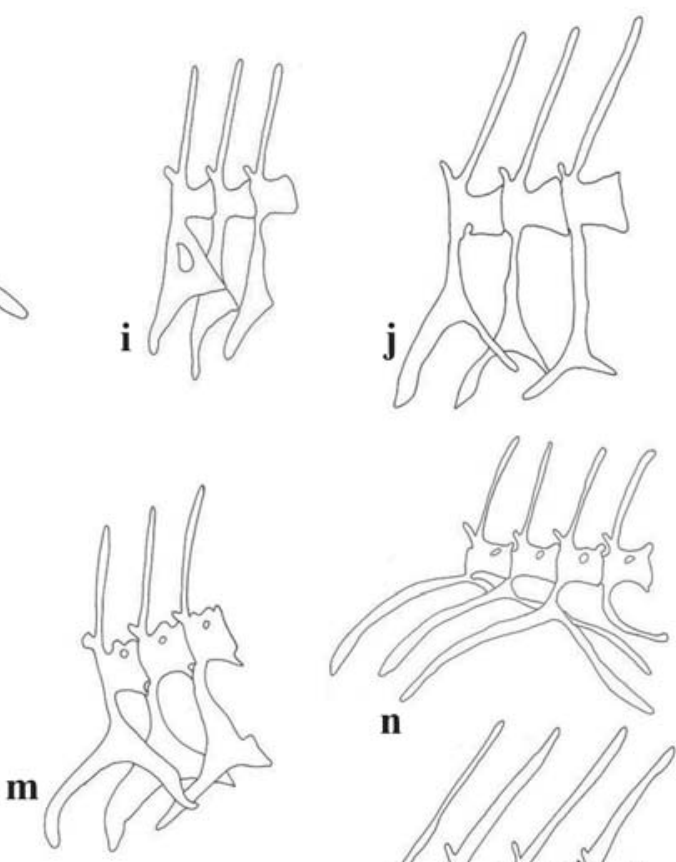

n
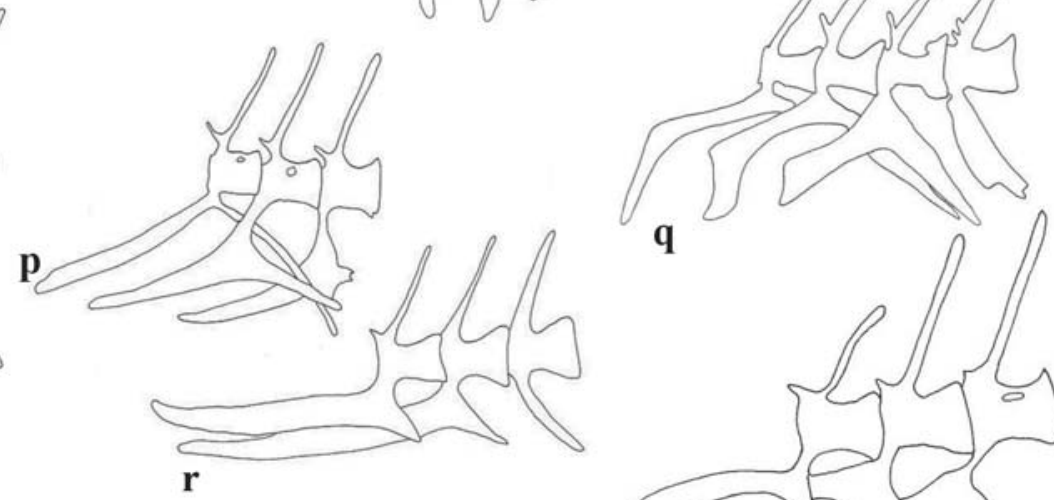

o

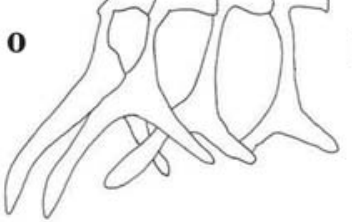

q

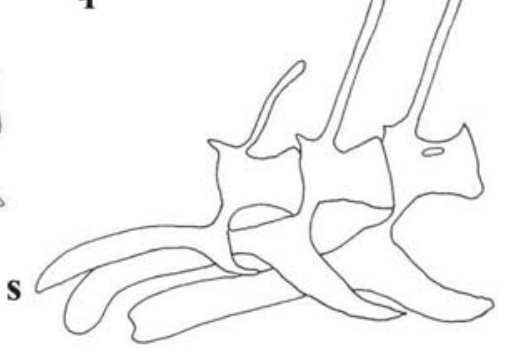

$\mathrm{e}, \mathrm{i}, \mathrm{j}, \mathrm{m}$

a-d, f-h, k-l, n-0

q-s

Fig. 10. Lateral view of gonapophyses in: a) Brachyrhaphis olomina, TU 24997; b) Brachyrhaphis rhabdophora, TU 84483; c) Poeciliopsis pleurospilus, USAC 838; d) Brachyrhaphis episcopi, SU 50303; e) Xiphophorus alvarezi, USAC 1782; f) Brachyrhaphis terrabensis, AMNH 20503; g) Phallichthys fairweatheri, USAC 1797; h) Poecilia rositae, USAC 1822; i) Priapichthys annectens, TU 25193; j) Pseudoxiphophorus bimaculatus, CAS 78795; k) Poeciliopsis turrubarensis, TU 24130; I) Pseudoxiphophorus obliquus, LSUMZ 14339; m) Poeciliopsis gracilis, TU 84966; n) Phalloceros caudimaculatus, MCP 40527; o) Pseudoxiphophorus litoperas, USAC 1813; p) Gambusia affinis, TU 114758; q) Heterandria formosa, TU 24002; r) Pamphorichthys araguaiensis, MCP 40919; s) Phalloptychus iheringi, MCP 11054. Scale bars $=1 \mathrm{~mm}$. 
125. Position of functional gonapophyses (Lucinda \& Reis, 2005, ch. 49): (0) between vertebrae 12-13 or 13-14, (1) between vertebrae 13-15, (2) between vertebrae 13-16, (3) between vertebrae $15-19$ or $15-17$.

126. First gonapophysis reduced to a support for adjacent gonapophyses located between vertebrae 12-13 (Rodriguez, 1997, fig. 4b; Lucinda \& Reis, 2005, ch. 50): (0) absent, (1) present.

127. Hollister's foramen on first or second gonapophyses (Rodriguez, 1997, ch. 7, fig. 4b; Lucinda \& Reis, 2005, ch. 51; Fig. 10): (0) absent, (1) present.

128. Shape of gonapophysis at vertebra 14 (Rosen \& Bailey, 1963, figs. 24a, 26c-d, 29b, 46, 56a-d; Lucinda \& Reis, 2005, ch. 52; Fig. 10): (0) same as other vertebrae, (1) rudimentary, (2) straight, (3) forming an acute angle, (4) curved.

Scales and pigmentation:

129. Number of lateral-line scales in male (Lucinda \& Reis, 2005, ch. 125): (0) less than 23, (1) 24-25, (2) 26-27, (3) 28-29, (4) more than 30.

130. Dorsal-fin pigment (Rosen, 1979): (0) diffuse spots among rays, (1) diffuse spots only at the tips, (2) pigmented rays, (3) one spot at the base.

131. Dorsal-fin melanophores forming two or more rows of discrete spots and anal-fin melanophores (Rosen, 1979): (0) not extending distally from the anal-fin base as streaks in interradial membrane, (1) extending distally from the analfin base as streaks in interradial membrane.

132. Anal-fin pigmentation (Rosen, 1979): (0) small pigment spots at distal fin margin, (1) small pigment spots along the fin, (2) pigments at the base, (3) large pigment spots in the fin base.

133. Basicaudal spot (Rosen, 1979): (0) absent, (1) present.

134. Basicaudal spot in adults partly or wholly above lateral line and extending onto caudal-fin base (Rosen, 1979): (0) absent, (1) present.

135. Basicaudal spot large spherical dusky filling area between midlateral line and dorsal margin of caudal-fin peduncle (Rosen, 1979): (0) absent, (1) present.

136. Pigment of scale pockets forming a strong reticular network along the sides of the body (Rosen, 1979): (0) absent, (1) present.

137. Midlateral pigment stripe (Rosen, 1979; Ghedotti, 1998, ch. 62): (0) slight line, (1) diffuse, formed by small dots, (2) single large dot at mid body, (3) strong, formed by small dots, (4) strong formed by large dots, (5) strongly developed.
138. Crosshatching on the body (Rosen, 1979): (0) welldeveloped, (1) diffuse.

139. Elongate vertical bars on the lateral surface of the body (Lucinda \& Reis, 2005, ch. 133): (0) absent, (1) present.

140. Sexual dimorphism in color pattern (Costa, 1998, ch. 106): (0) absent, (1) present.

Body proportions:

141. Adult sexual size dimorphism (Ghedotti, 2000, ch. 95): (0) no difference between sexes, (1) females larger, (2) males larger.

142. Body shape (Rosen, 1979; Ghedotti, 2000, ch. 98): (0) abrupt transition between abdomen and caudal peduncle, (1) no defined transition between abdomen and caudal peduncle.

143. Mouth terminal (Ghedotti, 1998): (0) absent, (1) present.

Cephalic sensory system

144. Posterior supraorbital canal (pores 2b, 3, 4a) (Costa, 1998, ch. 98; Ghedotti, 2000, ch. 90; Lucinda \& Reis, 2005, ch. 5): (0) pore present, open, forming a depression, (1) pore present, closed (Gosline, 1949, plate II, figs. 1, 4), (2) pore absent or forming a shallow groove (Rosen \& Mendelson, 1960, figs. 3B, J-M).

145. Lachrymal canal in adults (Ghedotti, 2000, ch. 91): (0) closed canal, forming pores, (1) open canal.

146. Preorbital canal (Rosen \& Mendelson, 1960, fig. 2; Lucinda \& Reis, 2005, ch. 9): (0) present open, (1) present closed, (2) absent.

147. Anterior section of posterior remnant of infraorbital system (pore 4b, 5, 6a) (Lucinda \& Reis, 2005, ch. 6): (0) pores closed, not visible, (1) pores were absent, forming a groove (Rosen \& Mendelson, 1960, figs. 3a-e, g-p), (2) pores were closed, forming a depression (Gosline 1949, plate II, figs. 1, 4), (3) pores were closed forming a groove, (4) pores open, forming a depression, (5) pores open, forming a groove.

148. Posterior section of posterior remnant of infraorbital system (canal 6b, 7) (Lucinda \& Reis, 2005, ch. 7): (0) open (Rosen \& Mendelson, 1960, figs. 2a-b), (1) closed (Gosline, 1949, plate II, fig. 4; Parenti, 1981, fig. 14a).

149. Preopercular canal (Lucinda \& Reis, 2005, ch. 8): (0) absent (Rosen \& Mendelson, 1960, figs. 2a-b), (1) present (Gosline, 1949, plate II, fig. 2).

150. Nasal canal (Parenti, 1981): (0) large, (1) reduced. 
Appendix 3. Data matrix of 150 characters for 52 poeciliine and four outgroup taxa. "?" indicates a character not coded due to lack of specimens, structures, or inapplicable codings. $\mathrm{P}=0 \& 1 ; \mathrm{Q}=0 \& 2 ; \mathrm{R}=1 \& 3 ; \mathrm{S}=1 \& 4 ; \mathrm{T}=0 \& 1 \& 2$.

Profundulus guatemalensis

Jenynsia eirmostigma

Anableps dowi

Fluviphylax pygmaeus

Tomeurus gracilis

Alfaro cultratus

Alfaro huberi

Belonesox belizanus

Brachyrhaphis episcopi

Brachyrhaphis olomina

Brachyrhaphis rhabdophora

Brachyrhaphis terrabensis

Carlhubbsia stuarti

Cnesterodon decemmaculatus

Gambusia affinis

Heterandria anzuetoi

Heterandria bimaculatus

Heterandria cataractae

Heterandria diremptus

Heterandria formosa

Heterandria litoperas

Heterandria obliquus

Limia dominicensis

Limia melanogaster

Micropoecilia branneri

Xenophallus umbratilis

Neoheterandria tridentiger

Pamphorichthys araguaiensis

Phallichthys amates

Phallichthys fairweatheri

Phalloceros caudimaculatus

Phalloptycus iheringi

Poecilia butleri

Poecilia latipinna

Poecilia mexicana

Poecilia retropinna

Poecilia rositae

Poecilia salvatoris

Poecilia sphenops

Poeciliopsis elongate

Poeciliopsis fasciata

Poeciliopsis gracilis

Poeciliopsis infans

Poeciliopsis latidens

Poeciliopsis lucida

Poeciliopsis lutzi

Poeciliopsis pleurospilus

Poeciliopsis presidionis

Poeciliopsis prolifica

Poeciliopsis turrubarensis

Poeciliopsis viriosa

Priapichthys annectens

Quintana atrizona

Scolichthys greeenwayi

Xiphophorus alvarezi

Xiphophorus mayae

\begin{tabular}{|c|c|c|c|c|}
\hline 1234567890 & $\begin{array}{l}1111111112 \\
1234567890\end{array}$ & $\begin{array}{l}2222222223 \\
1234567890\end{array}$ & $\begin{array}{l}3333333334 \\
1234567890\end{array}$ & $\begin{array}{l}4444444445 \\
1234567890\end{array}$ \\
\hline 0000000000 & 0001100101 & 0000000000 & 0000000000 & 0300000000 \\
\hline 1110122221 & 1002200002 & 1000011002 & 1010000111 & 0300101110 \\
\hline 1111002001 & 1002100002 & 1001010110 & 0000101111 & 0301101111 \\
\hline 2110201021 & 1002110322 & 0112001110 & 1010110101 & 1010000010 \\
\hline 1110101111 & 1100210211 & 0100100112 & 0110100001 & 1221011010 \\
\hline 2010011011 & 1100211022 & 0001100000 & 0100100101 & 1200000000 \\
\hline 1011011011 & 1100211020 & 0002100210 & 0110000001 & 0300001010 \\
\hline 1110001021 & 0100211022 & 0100100211 & 1110011110 & 1200000010 \\
\hline 1010000011 & 1102211022 & 0000100002 & 1100110110 & 1100001000 \\
\hline 1111002011 & 1002211122 & 0100100212 & 1100110111 & 0200000010 \\
\hline 1012010011 & 1002211132 & 0000100211 & 1100110111 & 1221001010 \\
\hline 1012110011 & 1002211122 & 0001100201 & 1100110111 & 0300001010 \\
\hline 1010110011 & 1010110202 & 0001100202 & 0110100100 & 1200000010 \\
\hline 1012120021 & 1000110112 & 0101100112 & 1110100100 & 1110110000 \\
\hline 1110001021 & 1100211022 & 0000100012 & 1110110011 & 1200000010 \\
\hline 2011010021 & 1112210022 & 0100100002 & 1100100211 & 1310011010 \\
\hline 2011110011 & 0012210012 & 0001100210 & 1110100111 & 1210000000 \\
\hline 2012010021 & 1112210022 & 0000100002 & 1100100211 & 0210011000 \\
\hline 2011010021 & 1112210022 & 0100100002 & 1100100201 & 0210010000 \\
\hline 1112110211 & 0002110031 & 0001100012 & 0100100111 & 1010000010 \\
\hline 1111101011 & 1010211022 & 0001100012 & 1110100111 & 1200111010 \\
\hline 2011010021 & 1112210022 & 0101100002 & 1110100201 & 0310010000 \\
\hline 1010112211 & 1012110212 & 0001101010 & 0110100100 & 1310110000 \\
\hline 0010212211 & 1012110212 & 0001101010 & 0110100000 & 1310110010 \\
\hline 1010020001 & 1102110130 & 0001101100 & 1110000011 & 1210101010 \\
\hline 1111200101 & 1012111112 & 0101100010 & 0101100002 & 1300000010 \\
\hline 1111000101 & 1012111112 & 0101100010 & 0101100002 & 1100000010 \\
\hline 2010100001 & 1000110132 & 0000100012 & 1110100101 & 1000011010 \\
\hline 1011200001 & 1012110122 & 0100100012 & 0100100100 & 1100100010 \\
\hline 1011120001 & 1012110122 & 0100100012 & 0100100100 & 1100100010 \\
\hline 1110110001 & 1001010110 & 0100100212 & 0110100110 & 1110110011 \\
\hline 2010102021 & 1000011332 & 0000101012 & 1110100101 & 1010111010 \\
\hline 1010120001 & 1001011200 & 0000100000 & 0110000100 & 0300000000 \\
\hline 0010120001 & 1000110222 & 0000100000 & 1110100100 & 1000100000 \\
\hline 1010121001 & 1002110221 & 0000100012 & 0110100100 & 1300111010 \\
\hline 1010120001 & ?012110210 & 0000100012 & 1110000100 & 0300000010 \\
\hline 1010100011 & 1001010222 & 0001100012 & 0110100100 & 1200010010 \\
\hline 1010100001 & 1000110201 & 0000100000 & 1110100100 & 1200010000 \\
\hline 1010120001 & 1002010202 & 0000100002 & 1110100100 & 1300000010 \\
\hline 1111120001 & 1012110111 & 0001101000 & 0110100100 & 1300110010 \\
\hline 1011021011 & 1002110111 & 0001001101 & 1101001001 & 1301100001 \\
\hline 1010101001 & 1001110122 & 0000100110 & 0100100100 & 1200110010 \\
\hline 1011310001 & 1011110111 & 0000101012 & 0100100100 & 1200110010 \\
\hline 0011010111 & 1011010112 & 0100101110 & 1100100100 & 1200100010 \\
\hline 1010101001 & 1012110112 & 0100101110 & 1100100100 & 1200110010 \\
\hline 1010121011 & 1001110102 & 0000101020 & 1100100100 & 1100100010 \\
\hline 1010121001 & 1012110112 & 0000101020 & 0100100100 & 1101010010 \\
\hline 1010011001 & 1001010102 & 0100100012 & 1100100100 & 1300100010 \\
\hline 2010021101 & 1110110112 & 0000101120 & 1100100101 & 1200100000 \\
\hline 1010110001 & 1001010101 & 0000100021 & 0100100101 & 1300100010 \\
\hline 1111210011 & 1111110122 & 0000101120 & 0110100100 & 1300000010 \\
\hline 1011000111 & 1012211122 & 0000100220 & 1110000110 & 0200100010 \\
\hline ? ?1? ????? 1 & ? ?? ??10101 & 0000101010 & ?110100100 & $1 ? 00100010$ \\
\hline 1012010011 & 1110110233 & 0100100120 & 1101100100 & 1100010000 \\
\hline 1012311111 & 1002110122 & 0101101020 & 0110100201 & 1200100010 \\
\hline 1012320011 & 1002210112 & 0001101020 & 0110100201 & 1200100010 \\
\hline
\end{tabular}


Appendix 3 (cont.). Data matrix of 150 characters for 52 poeciliine and four outgroup taxa. "?" indicates a character not coded due to lack of specimens, structures, or inapplicable codings. $\mathrm{P}=0 \& 1 ; \mathrm{Q}=0 \& 2 ; \mathrm{R}=1 \& 3 ; \mathrm{S}=1 \& 4 ; \mathrm{T}=0 \& 1 \& 2$.

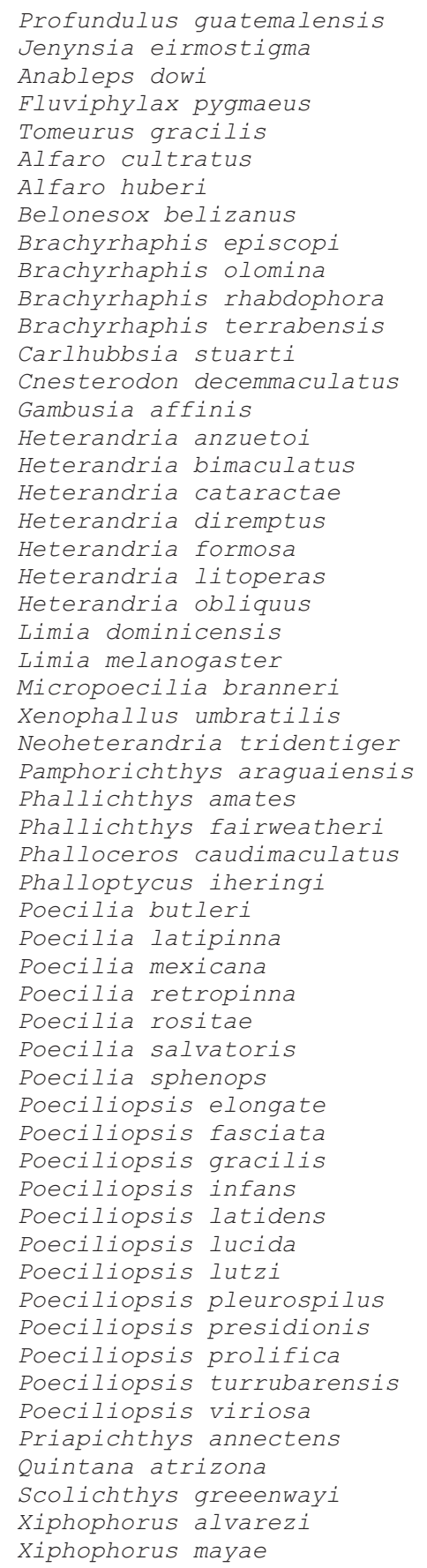
0000000000

\begin{tabular}{l}
0000000000 \\
1235555556 \\
\hline $01010000 ?$
\end{tabular}

$01010000 ? 0$

0100000000

$11010000 ? 0$

1001010000

0111112000

0111012000

0101210000

0101211000

0101211000

0101212000

0101211000

0101012000

1111110000

0101210000

1111011000

1101011000

1111110000

1111112000

1101011000

1111010000

1111010000

1101011100

0111011100

$0100 ? 12000$

0101011000

0101011000

1102112011

0101011000

0101011000

1101110000

1002111000

0101012000

0111212000

1101012000

0101?12000

1101012000

1111012000

0101012000

1101111000

0100110000

1111210000

0101010000

0101010000

0101210000

0100?1?000

1100010000

0111010000

0111110000

0111011000

0101010000

0111010000

0101?1?000

1101010000

0101212000

0101212000

0000000000

$0000000000 \quad 0000000000$

$\begin{array}{lll}0000000 & 000000000 & 0000000000\end{array}$

$1234567890 \quad 1234567890 \quad 1234567890$

$0000110300 \quad 0000200 ? ? 0$ ?????0????

$0130135300 \quad 0213211110 \quad 0100000200$

$0100255500 \quad 10101111 ? 3$ ????000?0?

0130250300 0Q03010??0 ?????0????

?030202000 03030220?3 ?000000?10

$0150255310 \quad 1100222023$

$0120154300 \quad 0300212023$

$0110255311 \quad 0200132002$

?141223311

?130222301

1111222301

0130224311

0020100421

0120225421

0110245311

0140014201

0130004121

0120003221

1120012201

1100234311

0150024221

0120024221

?15120030?

?151211301

11112?1301

?151233311

?151244311

?131212311

?141100301

?111110311

0141245411

1051124301

?021112310

?120102301

? 030112301

?130112301

?131112301

?140102301

?120122201

1151224321

1121244311

1151222321

0141233321

0151244321

0121244321

1131244301

0131222321

0151244311

1151234311

0151233321

?121231311

1151133321

?13022130?

?131244301

?151003301

1151001301
0000222011

0001242001

0303242001

00002 R2001

020133200 ?

1203111011

1002112001

0302202002

1301202012

0202202002

1101212012

1000042011

1103212022

0401402011

0202302011

0202312011

040110200 ?

1000242011

1000222011

0203012000

1003212011

1400222021

1102122001

0300112011

1003311012

0200302001

1200102011

0200302001

1100202011

1000202001

0200302001

1 ? 00202021

1003202021

0002232021

1102132021

1003112021

1102212021

03032120?1

1103212021

1003212021

0202112021

0400212021

$11022 \mathrm{R} 2021$

0200312021

02032120?1

1003212021

0202402011

0202202000
0111000000

0111000100

0010000200

0030000001

1010000200

1030000001

1010000001

1131000100

?130100401

0010000011

0010000101

0010000201

1010000101

1010000101

1010000101

1010000001

1010000101

0011000101

1011000201

1011000001

0010000001

0010000101

0031000101

1130000101

1110000301

1030100201

0110000301

1121010000

1021010101

1021010201

1021010201

0121010001

1021010201

1031010201

0110000101

0110000301

0120000301

0110000301

0110000101

0110000101

?1??00010?

01??000?0?

0110000101

0110000001

0110000301

????000?0?

0020000101

?1?0000101

0020000101

1030001101

1030001101

0000000001

9999999990

1234567890

?????????

0000000000

0 ????00000

?????0????

0000000000

0112100000

$0 ? 10000000$ 
Appendix 3 (cont.). Data matrix of 150 characters for 52 poeciliine and four outgroup taxa. "?" indicates a character not coded due to lack of specimens, structures, or inapplicable codings. $\mathrm{P}=0 \& 1 ; \mathrm{Q}=0 \& 2 ; \mathrm{R}=1 \& 3 ; \mathrm{S}=1 \& 4 ; \mathrm{T}=0 \& 1 \& 2$.

\begin{tabular}{|c|c|c|c|c|c|}
\hline & $\begin{array}{l}1111111111 \\
0000000001 \\
1234567890\end{array}$ & $\begin{array}{l}111111111 \\
1111111112 \\
1234567890\end{array}$ & $\begin{array}{l}1111111111 \\
2222222223 \\
1234567890\end{array}$ & $\begin{array}{l}1111111111 \\
3333333334 \\
1234567890 \\
\end{array}$ & $\begin{array}{l}1111111111 \\
4444444445 \\
1234567890 \\
\end{array}$ \\
\hline Profundulus guatemalensis & ?????????? & ???00?0??? & ???????010 & 0?0?????00 & 0000001000 \\
\hline Jenynsia eirmostigma & $00001000 ? 0$ & 0012020012 & 0 ???3?? 140 & 0?0????101 & 1111115110 \\
\hline Anableps dowi & 0000 ? ????? & ??????00?? & 0 ??????? 40 & 010 ?? ?5?00 & ?112005110 \\
\hline Fluviphylax pygmaeus & ?? ?0?00??? & ???00?0??? & ??????? 030 & 0 ? 0 ?? ?? 100 & 2101103010 \\
\hline Tomeurus gracilis & 0000400000 & $10000 ? 0100$ & $00 ? 0 ? 0014 ?$ & $0 ? 0 ? ? ? 0100$ & 0102014101 \\
\hline Alfaro cultratus & 0000211111 & 0010101111 & $112120014 ?$ & 0 ? 0 ?? ?? 100 & 1002124011 \\
\hline Alfaro huberi & 0000201111 & 0021101111 & 1121100140 & 010 ?? ??100 & 1002124111 \\
\hline Belonesox belizanus & 0000000002 & 0000020312 & 1112200340 & $0 ? 100 ? ? 000$ & 2101022101 \\
\hline Brachyrhaphis episcopi & 0000000101 & 1010110211 & 0111100422 & $03100 ? 5000$ & 1001005011 \\
\hline Brachyrhaphis olomina & 0000000101 & 1010010211 & 0002110332 & 020 ???1011 & 1002005011 \\
\hline Brachyrhaphis rhabdophora & 0000011112 & 1020010211 & $0102100 ? 32$ & 020 ????011 & $1 \mathrm{P} 01101011$ \\
\hline Brachyrhaphis terrabensis & 0000001111 & 1022020211 & 0112101412 & 020 ???1011 & 1001001011 \\
\hline Carlhubbsia stuarti & 0000300003 & 0122020112 & 0122101110 & 010 ????011 & 2001021011 \\
\hline Cnesterodon decemmaculatus & 0001411104 & 1022100113 & $00 ? 0 ? 00020$ & $0 ? 0 ? ? ? 3000$ & 1101011111 \\
\hline Gambusia affinis & 0000000002 & 0000020312 & 1112100430 & 0 0?????100 & 0101023101 \\
\hline Heterandria anzuetoi & 1110200101 & 0021020112 & 0112100420 & $101101 ? 011$ & 1101111011 \\
\hline Heterandria bimaculatus & 1110100101 & 0010010112 & 0112100410 & $111111 ? 001$ & 1101001011 \\
\hline Heterandria cataractae & 1110201103 & 0021110112 & 0112100330 & $111101 ? 000$ & 1101011111 \\
\hline Heterandria diremptus & 1110200101 & 0021120112 & 0112100440 & $111111 ? 010$ & 1101111011 \\
\hline Heterandria formosa & 0000201111 & 1010000112 & 0102201453 & $021000 ? 111$ & 1102012001 \\
\hline Heterandria litoperas & 1110200101 & 0020120112 & 0122201222 & 1111011000 & 1101001011 \\
\hline Heterandria obliquus & 1110200101 & 0021110112 & 0112100430 & $111101 ? 000$ & 1101111011 \\
\hline Limia dominicensis & 0000201111 & 0122120112 & $00 ? 1301202$ & 0 ?0?????11 & $1 P 01000001$ \\
\hline Limia melanogaster & 0000301111 & 0010020112 & $00 ? 1001200$ & $01100 ? ? 001$ & $1 \mathrm{P} 01001011$ \\
\hline Micropoecilia branneri & 0000301111 & 0000010114 & $00 ? 1101320$ & $0 ? 100 ? ? 1 ? ?$ & ?101021011 \\
\hline Xenophallus umbratilis & 0000000111 & 1122120111 & 0012101211 & 0 ? 0 ???? 100 & 1102001011 \\
\hline Neoheterandria tridentiger & 0000200111 & 1122120111 & 0011101210 & 0 ? 0????000 & 1102001011 \\
\hline Pamphorichthys araguaiensis & 0000101011 & 0000110100 & $00 ? 1011220$ & 0 ?0????101 & 1101013111 \\
\hline Phallichthys amates & 0000201111 & 0010010112 & 0122000400 & $00100 ? ? 000$ & 0001111011 \\
\hline Phallichthys fairweatheri & 0000101111 & 0012120114 & 0122100401 & 010 ????010 & 0001111011 \\
\hline Phalloceros caudimaculatus & 0000201000 & 0022120112 & 0122311430 & $0 ? 0 ? ? ? 2000$ & 1101012001 \\
\hline Phalloptycus iheringi & 0000500001 & 0022100113 & 1122100220 & 0 ? 0 ?? ?5110 & 1101101111 \\
\hline Poecilia butleri & 0000511111 & 0001100112 & $002101101 ?$ & 0 ?0????? 10 & 0101101101 \\
\hline Poecilia latipinna & 0000011013 & 0010120113 & 0011101110 & 0?0????000 & 1001002011 \\
\hline Poecilia mexicana & 0000001111 & 0010020112 & $00 ? 1101420$ & 0 ? 0 ?? ?? 000 & 1001011011 \\
\hline Poecilia retropinna & 0000011111 & 0010020112 & $00 ? 1101420$ & 0 ? 0 ?? ? ?000 & 1001002011 \\
\hline Poecilia rositae & 0000311113 & 0010120112 & $00 ? 1101410$ & 0?0????000 & 1101004011 \\
\hline Poecilia salvatoris & 0000311112 & 0022120111 & $00 ? 110142 ?$ & 0 ? 0 ?? ? 1000 & 1001002011 \\
\hline Poecilia sphenops & 0000311112 & 0022120112 & 0001001400 & 0 ? 0 ?? ? 1000 & 1001002011 \\
\hline Poeciliopsis elongate & 0000001111 & 0110020112 & $111110023 ?$ & 0 ?0????100 & 1101001001 \\
\hline Poeciliopsis fasciata & 0000101111 & 0022020112 & $111110043 ?$ & $0 ? 0$ ????010 & 1101001001 \\
\hline Poeciliopsis gracilis & 0000101111 & 0022020112 & $111120142 ?$ & $0 ? 0$ ?? ?3000 & 1101002001 \\
\hline Poeciliopsis infans & 0000101111 & 0012020113 & $111110140 ?$ & 0 ?0???? 100 & 1102000101 \\
\hline Poeciliopsis latidens & 0000101110 & 0022020113 & $111110141 ?$ & 0 ?0????010 & 1101001001 \\
\hline Poeciliopsis Iucida & 0000101111 & 0022020113 & $111210122 ?$ & $0 ? 0$ ?? ?5000 & 1101000011 \\
\hline Poeciliopsis lutzi & $00001 ? 1111$ & 0022020113 & 1112101210 & $020 ? ? ? 1000$ & 1101002011 \\
\hline Poeciliopsis pleurospilus & $00001 ? 1111$ & 0022020112 & 1111101230 & 020 ?? ? 4001 & 1101103011 \\
\hline Poeciliopsis presidionis & 0000101111 & 0022020113 & $111210140 ?$ & $0 ? 0 ? ? ? 3000$ & 1100002111 \\
\hline Poeciliopsis prolifica & 0000101111 & 0012010113 & $111110143 ?$ & 0 ? 0 ? ? ? 3000 & 1101112101 \\
\hline Poeciliopsis turrubarensis & 0000101112 & 0012020113 & 1112101430 & 0?0????011 & 1101003011 \\
\hline Poeciliopsis viriosa & 00001 ????? & ???2?20113 & 1012101410 & $0 ? 0 ? ? ? 0000$ & 1101002011 \\
\hline Priapichthys annectens & 0000201101 & 0022120123 & 1112101120 & 0 ? 0 ?? ? ?000 & 1101001111 \\
\hline Quintana atrizona & $000020 ? 102$ & ?1???101?? & 0 ??2????03 & 0 ?0???001? & ?102002101 \\
\hline Scolichthys greeenwayi & 0000201101 & 1022120112 & 0011100430 & $0 ? 0$ ???2001 & 2101004011 \\
\hline Xiphophorus alvarezi & 0000211102 & 0110120113 & $00 ? 2200220$ & 0 ? 0 ?? ?5001 & 2001002011 \\
\hline Xiphophorus mayae & 0000211102 & 0012120111 & 0110200110 & 0 ?0???5101 & 2101101011 \\
\hline
\end{tabular}

